University of Nebraska - Lincoln

DigitalCommons@University of Nebraska - Lincoln

Papers in the Earth and Atmospheric Sciences

Earth and Atmospheric Sciences, Department

4-2009

\title{
Fluvial-estuarine reinterpretation of large, isolated sandstone bodies in epicontinental cyclothems, Upper Pennsylvanian, northern Midcontinent, USA, and their significance for understanding late Paleozoic sea-level fluctuations
}

\author{
Steven A. Fischbein \\ University of Nebraska-Lincoln, sfischbein2@unl.edu \\ R. Matthew Joeckel \\ University of Nebraska-Lincoln, rjoeckel3@unl.edu \\ Christopher R. Fielding \\ University of Nebraska-Lincoln, cfielding2@unl.edu
}

Follow this and additional works at: https://digitalcommons.unl.edu/geosciencefacpub

Part of the Earth Sciences Commons

Fischbein, Steven A.; Joeckel, R. Matthew; and Fielding, Christopher R., "Fluvial-estuarine reinterpretation of large, isolated sandstone bodies in epicontinental cyclothems, Upper Pennsylvanian, northern Midcontinent, USA, and their significance for understanding late Paleozoic sea-level fluctuations" (2009). Papers in the Earth and Atmospheric Sciences. 132.

https://digitalcommons.unl.edu/geosciencefacpub/132

This Article is brought to you for free and open access by the Earth and Atmospheric Sciences, Department of at DigitalCommons@University of Nebraska - Lincoln. It has been accepted for inclusion in Papers in the Earth and Atmospheric Sciences by an authorized administrator of DigitalCommons@University of Nebraska - Lincoln. 


\title{
Fluvial-estuarine reinterpretation of large, isolated sandstone bodies in epicontinental cyclothems, Upper Pennsylvanian, northern Midcontinent, USA, and their significance for understanding late Paleozoic sea-level fluctuations
}

\author{
S. A. Fischbein, ${ }^{1,2}$ R. M. Joeckel, ${ }^{2,3}$ and C. R. Fielding ${ }^{2}$ \\ 1. ANDRILL Science Management Office, 126 Bessey Hall, University of Nebraska-Lincoln, NE 68588-0341, USA \\ 2. Department of Geosciences, 214 Bessey Hall, University of Nebraska-Lincoln, Lincoln, NE 68588-0340, USA \\ 3. Conservation and Survey Division, School of Natural Resources, 615 Hardin Hall, \\ University of Nebraska-Lincoln, Lincoln, NE 68583-0996, USA \\ Corresponding author - S. A. Fischbein, tel 402 472-6268, fax 402 472-6724, email safischbein@earthlink.net
}

\begin{abstract}
The Upper Pennsylvanian Indian Cave Sandstone (ICS) in southeastern Nebraska is herein reinterpreted as three multistory incised valley fills and one single-storey channel fill, altogether representing at least two different intervals of time. ICS lithosomes are linear bodies, as much as $2000 \mathrm{~m}$ wide and $30 \mathrm{~m}$ thick, incised into pre-existing cyclothems, and have relatively steep sides and flat bases. They include crudely fining-upwards successions of trough cross-bedded sandstones, interpreted as tidally-influenced fluvial deposits, overlain by upper estuarine heterolithic facies, with local coals, and a restricted trace fossil assemblage. The vertical facies succession suggests sediment accumulation in a regime of gradually increasing accommodation, i.e., during rising relative sea level. The basal erosion surfaces of ICS bodies can be traced out onto the adjacent interfluves where they correspond to well-developed paleosols, indicating sequence boundaries. Furthermore, the sequences defined herein can be correlated closely with recently published sequence stratigraphic frameworks from the region, suggesting that the ICS bodies record repeated, fifth-order (Milankovitch band), relative sea-level fluctuations of a minimum of $30 \mathrm{~m}$ during latest Pennsylvanian time Significantly, this estimate is half or less of those made by many other studies. Such a local quantification of relative sea-level change provides a critical constraint on eustatic sea-level fluctuation during the late Paleozoic Gondwanan Ice Age.
\end{abstract}

Keywords: IVF, Pennsylvanian, sandstone, fluvial-to-estuarine, upper-estuarine, sequence-stratigraphy

\section{Introduction}

Large sandstone bodies $(<10 \mathrm{~m}$ to $>30 \mathrm{~m}$ thick and $<1 \mathrm{~km}$ to $>10 \mathrm{~km}$ wide) in Upper Pennsylvanian marine-dominated cyclothems of Midcontinent USA (Nebraska, Kansas, Oklahoma, Missouri, Iowa) indicate major shifts in facies tracts and significant fluctuations in relative sea level. Studying them can yield significant information for the interpretation of Late Pennsylvanian environmental change in the ancient subtropics. Although a few recent papers have demonstrated the sizeable information potential of these sandstone bodies (e.g., Archer et al., 1994; Feldman et al., 1995; Bowen and Weimer, 2003; Bowen and Weimer, 2004), their interpretation has been severely impaired in many cases by a lack of precise stratigraphic context and the absence of comprehensive facies analyses. In this study, we reappraise the sedimentology and sequence stratigraphy of the Indian Cave Sandstone (ICS), the most prominent Upper Pennsylvanian sandstone in southeastern Nebraska (Figure 1A, B), and one of the most well-known examples of its type in all of the Midcontinent.
The ICS has been the focal point of major stratigraphic interpretations for nearly a century (e.g., Barbour, 1914; Moore, 1936; Moore and Mudge, 1956; Mudge and Yochelson, 1962). The erosional surface at the base of the ICS was once considered to be a major disconformity representing the Pennsylvanian-Permian boundary (Moore, 1936). That boundary has since been moved upward by Baars et al., (1994a, 1994b), Davydov et al. (1998), and Sawin et al. (2006) (Figure 2). Ossian (1974) interpreted the ICS as an ancient constructional delta, thereby reflecting prevailing opinions on the origins of sandstone bodies in the Midcontinent and Appalachian Basin circa 1970-1980 (e.g., Ferm, 1974; Horne and Ferm, 1974; Heckel, 1980). After 1990, however, many such sandstone bodies were reinterpreted as incised valley fills (IVFs) on the basis of sediment body geometries and lithofacies analysis, and these reinterpretations revealed a richer record of depositional-system responses to sea-level change than was previously envisaged (e.g., Archer et al., 1994; Gibling and Bird, 1994; Feldman et al., 1995; Bowen and Weimer, 2003; Feldman et al., 2005). A parallel application of modern sedimentologic paradigms to the ICS in this paper leads to a new interpretation and 
A

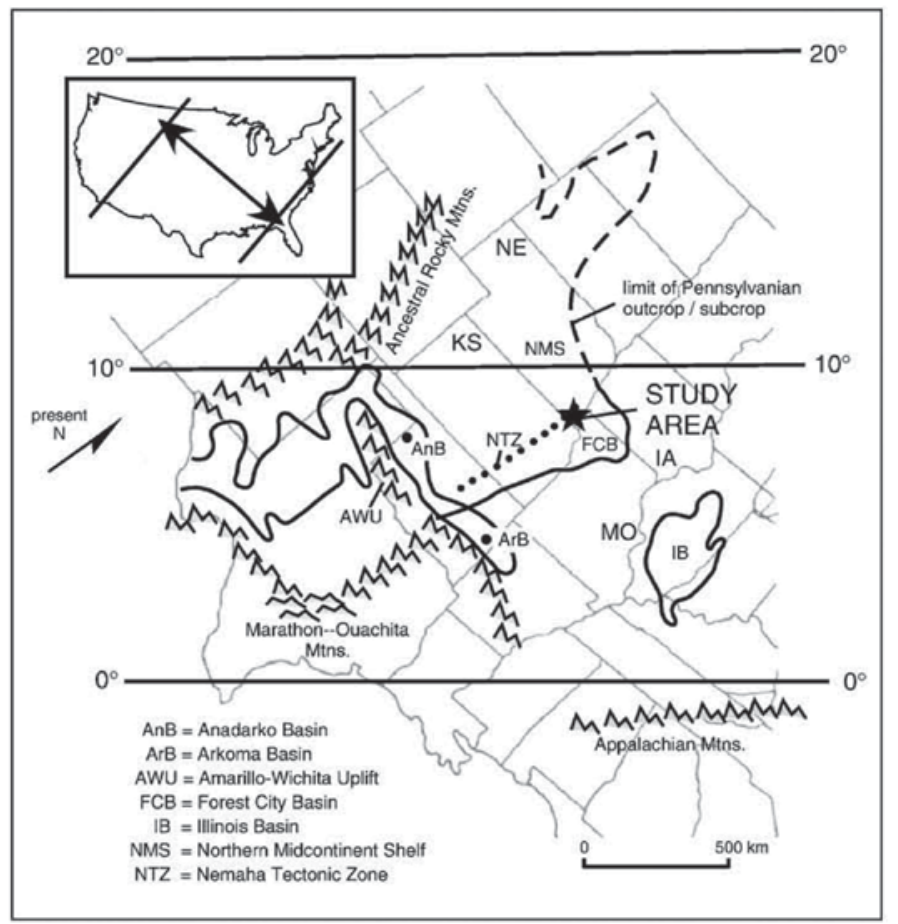

B

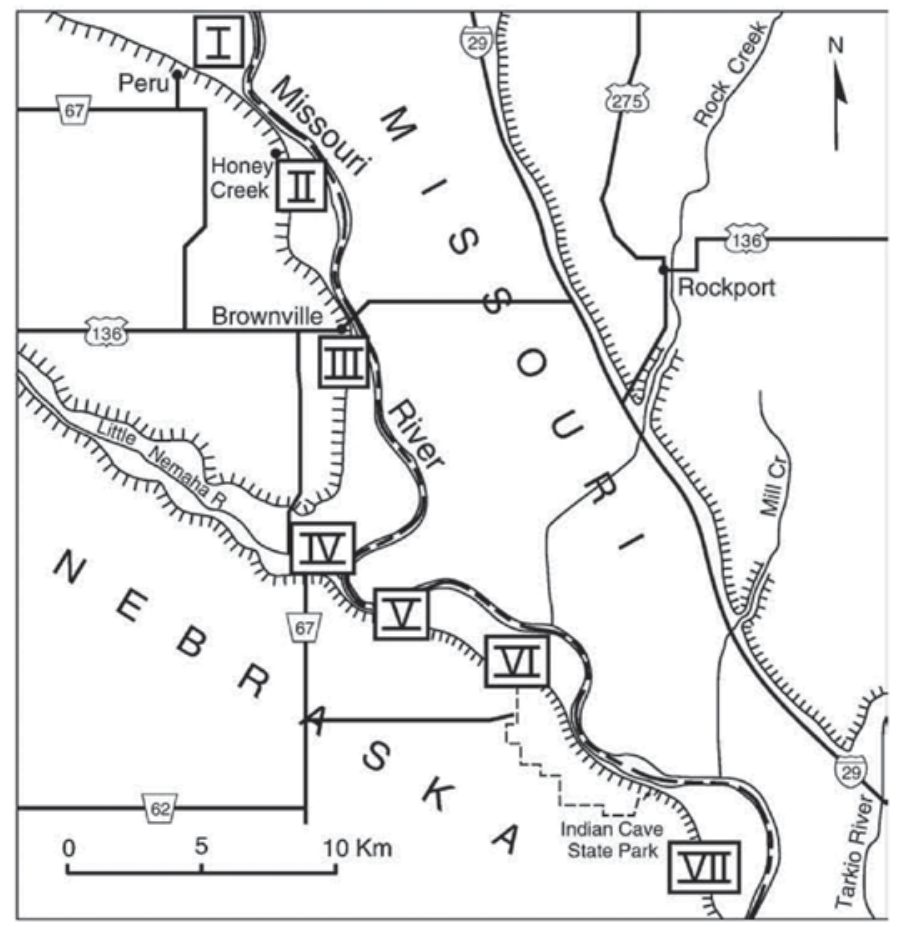

Figure 1. A) Location of study area (Pennsylvanian paleogeography modified from McKee and Crosby, 1975; Feldman et al., 2005). B) Primary study sites at Peru, Honey Creek, Brownville and Indian Cave State Park (ICSP), Nebraska. Roman numerals mark beginnings and ends of individual cross-section panels shown in Figure 4.

reveals a very important record of terrigenous sedimentation under conditions of high-frequency sea-level change and limited accommodation on an extremely low-gradient platform. Reexamination of the ICS also yields a highly useful case study in the application of sequence stratigraphy to cyclothems.

We examined four sites (Figure 1B) along $25 \mathrm{~km}$ of limited outcrop to assess the lateral consistency of named stratigraphic units, characterize ICS lithofacies, ascertain depositional environments, stratigraphic architecture, and sequence stratigraphy. Detailed stratigraphic correlations were then made between these sites, other outcrops, and a few rotary boreholes penetrating the study interval. On the basis of the data presented herein, we demonstrate that the ICS is a fluvial to estuarine incised valley fill constrained below by a sequence boundary and above by a maximum flooding surface. This interpretation allows esti- mation of minimum relative sea-level fall based on stratal thicknesses in IVF bodies in low gradient, low accommodation settings.

\section{Upper Pennsylvanian cyclothems of Midcontinent USA}

During the Pennsylvanian, the northern Midcontinent was a slowly-and passively-subsiding, low-relief, extremely low gradient $\left(10^{-1}\right.$ to $\left.10^{0} \mathrm{~m} / \mathrm{km}\right)$ epicontinental platform with imposed structural dips ranging no more than $0.15^{\circ}-0.25^{\circ}$ (Heckel, 1977, 1980; Olszewski and Patzkowsky, 2003). This platform was more than $500 \mathrm{~km}$ in width, bordered distantly to the south by the Marathon-Ouachita foreland system (Figure 1A). Under the combined conditions of fluctuating relative sea-level, limited input of clastic sediment, and low rates of regional subsid-
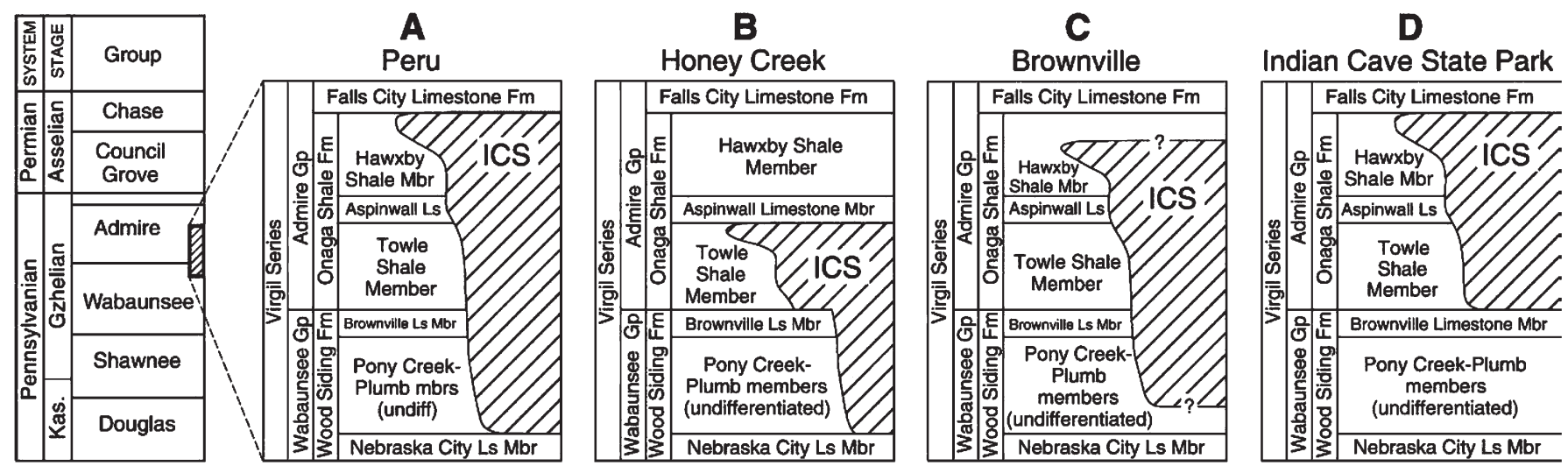

Figure 2. Generalized stratigraphic columns showing positions of Indian Cave Sandstone bodies at: A) Peru, B) Honey Creek, C) Brownville, D) Indian Cave State Park (ICSP), Nebraska. 
ence, repeated, short-interval stratigraphic cycles (cyclothems) dominated by mudrocks and carbonates were deposited across the region. Major, southwestward-flowing, continental drainage networks incised the exposed formerly inundated marine shelf and deposited "shoestring" sandstones in narrow tracts following major sea-level drawdowns (e.g., Archer et al., 1994; Feldman et al., 2005). In contrast to the several marine units (many thinner than $0.5 \mathrm{~m}$ ) in Midcontinent cyclothems that can be traced for hundreds of kilometers (e.g., Heckel, 1986, 1994; Olszewski and Patzkowsky, 2003), the areal distribution of these comparatively rare sandstone bodies is very limited.

The most widely-accepted model for Midcontinent Upper Pennsylvanian cyclothems is that of P. H. Heckel (e.g., Heckel, 1977, 1980, 1986, 1994, 2002). It invokes glacioeustatic sea-level changes in the Milankovitch band as the chief driving force and the main explanation for the lateral continuity of stratigraphic units. In the Heckel model, black, phosphatic "core" shales in the middle of individual cyclothems represent maximum water depths; transgressive deposits in such a cyclothem lie below its "core" shale and regressive deposits lie above it. Recently, a few attempts have been made to apply sequence stratigraphy to the Midcontinent Pennsylvanian succession (e.g., Olszewski and Patzkowsky, 2003; Feldman et al., 2005). Large sandstone bodies in cyclothem successions, being exceptional records of fluvial-system response, are unique but underutilized sources of data about sea-level change and the response of terrigenous clastic systems. Historically, these sandstone bodies were given specific names and depicted as discrete stratigraphic units in published stratigraphic columns (Mudge, 1956; Mudge and Yochelson, 1962; Heckel, 1994; Feldman et al., 1995; Heckel et al., 1998). We surmise, however, that these sandstone bodies are frequently too large, relative to the size of outcrops, to have been placed with uniform accuracy in local to regional stratigraphic contexts, and also that their significance could not have been fully real- ized without "modern" interpretational tools. A combination of detailed outcrop mapping and bed tracing using photomontages-practicable only with effort along the wooded bluffs of the Missouri River in the study area, critical re-evaluation of the local to regional stratigraphic scheme, lithofacies analysis, and the application of sequence stratigraphy together form the basis for new interpretations.

Researchers have struggled with geologic evidence to provide accurate estimates of minimum relative sea-level fluctuations associated with Late Paleozoic Gondwanan ice volume flux (e.g., Veevers and Powell, 1987; Crowley and Baum, 1991; Isbell et al., 2003; Rygel et al., 2008), producing estimates ranging from as much as 100-150 m (e.g., Heckel, 1994; Soreghan and Giles, 1999) to as little as 30-60 m (Crowley and Baum, 1991; Isbell et al., 2003). Until now, no single estimate has been generated by a quantifiable method, but sequence stratigraphy and the recognition of genetic surfaces provide the framework for doing so on the extremely low gradient Midcontinent platform (Joeckel, 1991; Miller and West, 1993; Joeckel, 1994; Heckel et al., 1998; Joeckel, 1999; Olszewski and Patzkowsky, 2003; Wardlaw et al., 2004). Minimum sea level fluctuations in this setting can be estimated by measuring the stratigraphic thickness between the sequence boundary and the maximum flooding surface (Fischbein, 2006).

\section{Lithostratigraphy of Indian Cave Sandstone (ICS)}

No official type section of the ICS has ever been designated, but its presumed type area is the current Indian Cave State Park (ICSP) in southeastern Nebraska, which includes the eponymous physiographic feature (Figure 1B). Sandstones in several other places in southeastern Nebraska, northwesternmost Missouri, eastern Kansas, and as far afield as north-central Oklahoma have all been called "Indian Cave Sandstone" in published literature (Moore and Moss, 1934; Moore, 1936; Mudge,

Table 1. Lithofacies codes, characteristics and interpretations.

\begin{tabular}{|c|c|c|c|c|}
\hline Facies code & Facies name & Lithology & Sedimentary structures & Interpretation \\
\hline $\mathrm{H}_{2}$ & $\begin{array}{l}\text { Mudstone-dominat- } \\
\text { ed heterolith }\end{array}$ & $\begin{array}{l}\text { Interlaminated and thinly interbedded mudstone } \\
\text { and very fine- to fine-grained sandstone: } 60- \\
80 \% \text { mudstone in laminae and beds } 1-300 \mathrm{~mm} \\
\text { thick, } 20-40 \% \text { sandstone } \\
\text { in laminae and beds } 1-500 \mathrm{~mm} \text { thick. }\end{array}$ & $\begin{array}{l}\text { Pinstripe (linsen), lenticular and wavy } \\
\text { bedding, microfaults, coaly plant debris, } \\
\text { rare, simple faunal traces (Planolites, } P a- \\
\text { laeophycus) }\end{array}$ & $\begin{array}{l}\text { Deposition of mud and sand from } \\
\text { lower flow regime, unidirec- } \\
\text { tional currents and from sus- } \\
\text { pension }\end{array}$ \\
\hline $\mathrm{H}_{1}$ & $\begin{array}{l}\text { Sandstone-dom- } \\
\text { inated hetero- } \\
\text { lith }\end{array}$ & $\begin{array}{l}\text { Interlaminated and thinly interbedded } \\
\text { sandstone and mudstone: } 40-80 \% \\
\text { sandstone in laminae and beds } 5-500 \mathrm{~mm} \\
\text { thick, } 20-60 \% \text { mudstone in laminae and beds } \\
1-500 \mathrm{~mm} \text { thick. }\end{array}$ & $\begin{array}{l}\text { Pinstripe (linsen), lenticular, wavy and fla- } \\
\text { ser bedding, ripple cross-lamination, flat } \\
\text { lamination, coaly plant debris, rare eu- } \\
\text { rypterid body fossils, rare, simple faunal } \\
\text { traces (Planolites, Conichnus) }\end{array}$ & $\begin{array}{l}\text { Deposition of sand and mud from } \\
\text { lower flow regime, unidirec- } \\
\text { tional currents and from sus- } \\
\text { pension. }\end{array}$ \\
\hline $\mathrm{S}_{\mathrm{L}}$ & $\begin{array}{l}\text { Low-angle cross- } \\
\text { bedded sand- } \\
\text { stone }\end{array}$ & $\begin{array}{l}\text { Fine- to medium-grained sandstone. } \\
\text { Intervals typically }<0.75 \mathrm{~m} \text { thick. }\end{array}$ & $\begin{array}{l}\text { Dominated by sets of low-angle }\left(<1-10^{\circ}\right) \\
\text { cross-bedding }<0.75 \mathrm{~m} \text { thick passing lat- } \\
\text { erally into flat lamination, minor ripple } \\
\text { cross-lamination, mudstone drapes and } \\
\text { mudstone clasts on some bedding planes. }\end{array}$ & $\begin{array}{l}\text { Migration of sediment waves in } \\
\text { transitional upper flow regime } \\
\text { conditions. }\end{array}$ \\
\hline $\mathrm{St}_{2}$ & $\begin{array}{l}\text { Small-scale trough } \\
\text { cross-bedded } \\
\text { sandstone }\end{array}$ & $\begin{array}{l}\text { Fine- to medium-grained sandstone, } \\
\text { erosionally-based intervals }<5 \mathrm{~m} \text { thick. }\end{array}$ & $\begin{array}{l}\text { Trough cross-bedding in sets }<0.25 \mathrm{~m} \\
\text { thick, mudstone clasts on basal scour } \\
\text { surfaces. }\end{array}$ & $\begin{array}{l}\text { ed, sandy dunes on channel } \\
\text { floors and bars. }\end{array}$ \\
\hline$S t_{1}$ & $\begin{array}{l}\text { Large-scale trough } \\
\text { cross-bedded } \\
\text { sandstone }\end{array}$ & $\begin{array}{l}\text { Fine- to medium-grained sandstone, } \\
\text { erosionally-based intervals }<5 \mathrm{~m} \text { thick. }\end{array}$ & $\begin{array}{l}\text { Trough cross-bedding in sets } 0.25-1.0 \mathrm{~m} \\
\text { thick, mudstone clasts on basal scour } \\
\text { surfaces, minor ripple cross-lamination } \\
\text { and mudstone drapes. }\end{array}$ & $\begin{array}{l}\text { Migration of large, sinuous crest- } \\
\text { ed, sandy dunes on channel } \\
\text { floors and bars. }\end{array}$ \\
\hline $\mathrm{Ci}_{\mathrm{h}}$ & $\begin{array}{l}\text { Intraformation- } \\
\text { al, monomic- } \\
\text { tic, heterolithic } \\
\text { clast conglomer- } \\
\text { ate }\end{array}$ & $\begin{array}{l}\text { Matrix- to clast-supported, very poorly to mod- } \\
\text { erately sorted, angular to subrounded granule } \\
\text { to cobble clast conglomerate and breccia, clasts } \\
\text { exclusively of mudrocks and heterolithic facies } \\
\text { with fine-grained sandstone matrix, erosional- } \\
\text { ly-based intervals }<1 \mathrm{~m} \text { (rarely, more) thick. }\end{array}$ & $\begin{array}{l}\text { Long axes of clasts define crude parallel } \\
\text { stratification, local clast imbrication. }\end{array}$ & $\begin{array}{l}\text { Coarse-grained lag on valley and } \\
\text { channel floors, disaggregation } \\
\text { of bank collapse masses. }\end{array}$ \\
\hline $\mathrm{Ci}_{\mathrm{b}}$ & $\begin{array}{c}\text { Basal, polymictic } \\
\text { conglomerate }\end{array}$ & $\begin{array}{l}\text { Matrix- to clast-supported, very poorly to mod- } \\
\text { erately sorted, very angular to subround- } \\
\text { ed, granule to boulder clast conglomerate and } \\
\text { breccia, clasts mostly of mudrock and lime- } \\
\text { stone with fine-to medium-grained sandstone } \\
\text { matrix, erosionally-based intervals }<2 \mathrm{~m} \text { thick. }\end{array}$ & $\begin{array}{l}\text { Chaotic to crudely flat-stratified, coalified } \\
\text { wood debris, rare vertebrate fossil frag- } \\
\text { ments. }\end{array}$ & $\begin{array}{l}\text { Coarse-grained lag overlying bas- } \\
\text { al incision surface on valley } \\
\text { and channel floors. }\end{array}$ \\
\hline
\end{tabular}



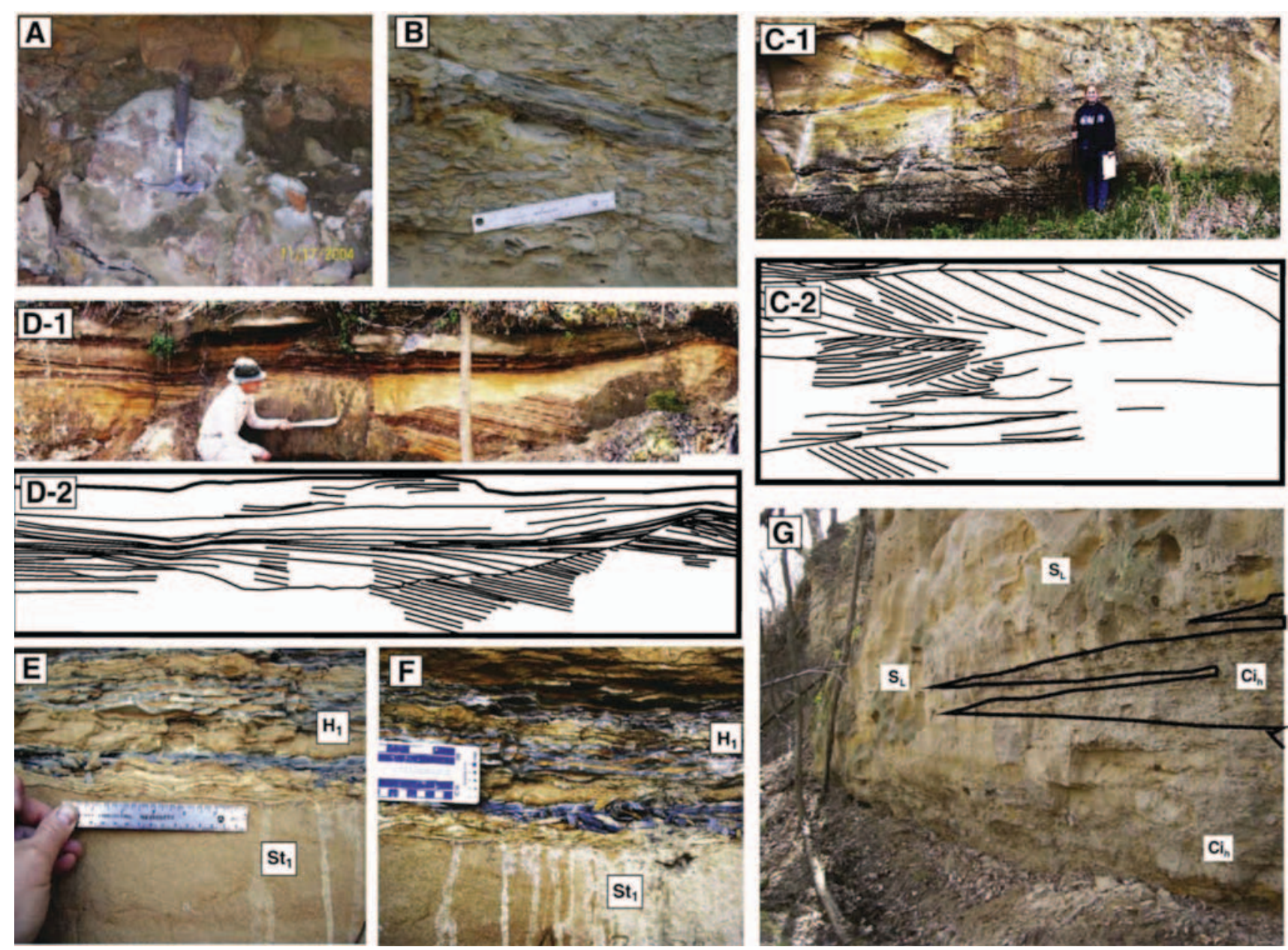

Figure 3. Lithofacies examples. A) Facies $\mathrm{Ci}_{b^{\prime}}$ basal conglomerate showing poorly sorted, angular to rounded pebbles to boulders of limestone and mudrocks. B) Facies $\mathrm{Ci}_{\mathrm{h}}$ containing clasts of heterolith eroded from subjacent and adjacent channel margins. C-1) Facies St $\mathrm{f}_{1}$ large scale trough cross-bedded sandstone. C-2) Line drawing of C-1 highlighting bed-scale architecture. D-1) Facies $\mathrm{S}_{\mathrm{L}}$ outcrop showing multiple sets of low-angle cross-bedding separated by scour surfaces (machete points to one scour surface). D-2) Line drawing of D-1 highlighting bed-scale architecture. E) and $\mathrm{F}$ ) Facies $\mathrm{H}_{1}$ and $\mathrm{St}_{1}$ showing $\mathrm{St}_{1}$ passing upward into $\mathrm{H}_{1}$, the latter comprising rhythmic alternations of siltstone and fine-grained sandstone. $\mathrm{G})$ Facies $\mathrm{Ci}_{\mathrm{h}}$ showing the local intercalated nature of Facies $\mathrm{Ci}_{\mathrm{h}}$ and Facies $\mathrm{S}_{\mathrm{L}}$, interpreted as bank collapse. $\mathrm{H}$ ) Facies $\mathrm{H}_{1}$ showing rhythmic mud draped ripple foresets and laminasets (to right of coin, thin mudstone drapes on thicker sandstone lamina) interpreted as tidal indicators (coin is $24 \mathrm{~mm}$ ). I) Facies $\mathrm{H}_{1}$ and $\mathrm{H}_{2}$ showing rhythmic mud draped laminasets and lenticular and flaser bedding interpreted as tidal indicators.

1956; Mudge and Yochelson, 1962; Ossian, 1974; Campbell et al., 1988; Mazzullo et al., 2005). Nonetheless, rigorous systematic correlations were never performed for the ICS, even between putative ICS sandstones cropping out along the Missouri River bluffs in the relatively small type area (Figure 1B). Therefore, the widespread application of the name across the Midcontinent, as well as the concept of genetic stratigraphy its usage implies, is at best slightly misleading and at worst entirely erroneous. This caveat might be applied with equal veracity to other Pennsylvanian IVF sandstones in the Midcontinent.

The ICS has always been considered a part of the Towle Shale in its type area (Moore, 1936; Mudge, 1956; Mudge and Yochelson, 1962; Ossian, 1974; Archer and Feldman, 1995) and it was traditionally thought to be underlain by the Brownville Limestone and overlain by the Aspinwall Limestone (Figure 2). Much to the contrary, our study demonstrates: (1) that the ICS in the type area occupies a higher stratigraphic position and is found between the Falls City and Brownville limestones (Figure 2D), and (2) that certain marine units bounding the study interval are continuous, but also (3) that sandstone bodies long considered to be part of one essentially continuous Indian Cave Sandstone are, in fact, separate entities having different stratigraphic positions and hence different depositional histories (Figure 2A-D).
At Peru, Nebraska the ICS lies between the Falls City and Nebraska City limestones (Figure 2A). In some outcrops along Honey Creek, Nebraska the ICS lies between the Aspinwall and Brownville limestones, but in other outcrops near Honey Creek and in recorrelated boreholes logs (Burchett, 1977) the ICS penetrates the Brownville Limestone and extends downward to the Nebraska City Limestone (Figure 2B). At Brownville, Nebraska the ICS is neither underlain by the Brownville Limestone nor overlain by the Aspinwall Limestone (Figure 2C).

\section{Lithofacies analysis of Indian Cave Sandstone (ICS)}

The ICS is part of a major clastic fairway consisting of large paleo-drainage networks trending towards the MarathonOuachita foreland (cf. Archer and Feldman, 1995). Lithofacies identifiable in the ICS are very distinctive in comparison with the typical lithofacies of regional cyclothems. Seven lithofacies appear in the ICS bodies (Table 1):

(1) $\mathrm{Ci}_{\mathrm{b}}$ (Basal, Polymictic Conglomerate), where it is present, overlies the basal erosion surface of ICS lithosomes. The largest clasts in this facies are marine limestones derived from the underlying cyclothems (Figure 3A). 

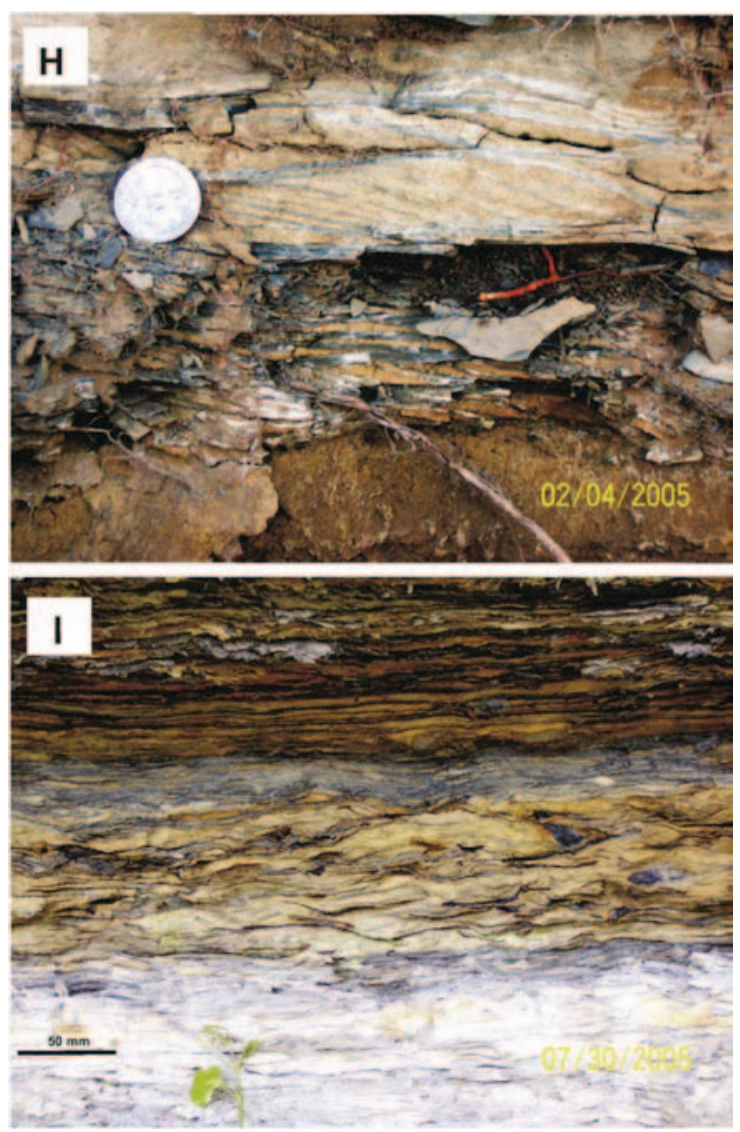

Figure 3 (continued).

(2) $\mathrm{Ci}_{\mathrm{h}}$ (Intraformational, Monomictic, Heterolithic Clast Conglomerate) contains only intraformational clasts, and lies directly atop internal storey-bounding surfaces (Figure 3B). Thick accumulations of Facies $\mathrm{Ci}_{h}$ appear near the steeplyincised margins of ICS bodies.

(3) $\mathrm{St}_{1}$ (Large-Scale, Trough Cross-Bedded Sandstone: Figure 3C-1 and C-2) typically overlies conglomerate facies, either at the base of ICS bodies or in the lower parts of storeys higher in the lithosome. Individual units of the facies can be traced for $100 \mathrm{~m}$ or more oblique to flow, and they pass laterally and upward into Facies $\mathrm{St}_{2}$. Flow depth estimates range from 8.6 to $14.3 \mathrm{~m}$, according to the method of Leclair and Bridge (2001) and paleoflow directions are dominantly to the southwest with measurements ranging from southwest to southeast.

(4) $\mathrm{St}_{2}$ (Small-Scale, Trough Cross-Bedded Sandstone) shows cross-sectional geometries similar to $\mathrm{St}_{1}$. Flow depth estimates range from 3.5 to $5.8 \mathrm{~m}$ for $\mathrm{St}_{2}$, according to the method of Leclair and Bridge (2001), and paleoflow directions dominantly to the southwest with measurements ranging from southwest to southeast.

(5) $S_{L}$ (Low-Angle Cross-Bedded Sandstone (Figure 3D-1 and D-2): appears in less laterally extensive, lens or wedge-shaped units interbedded with mudstone dominated heterolithic facies $\left(\mathrm{H}_{2}\right)$.

(6) $\mathrm{H}_{1}$ (Thinly-interstratified Sandstone-Dominated Heterolith: Figure 3E, F): Lamina (2-9 $\mathrm{mm}$ ) and laminasets of sandstone and silty sandstone with inter-lamina drapes of mudstone. Trace fossils of Planolites, plus coalified wood detritus and eurypterids are found in both the sandstone and mudstone lamina.

(7) $\mathrm{H}_{2}$ (Mudstone-Dominated Heterolith): Lamina ( $\leq 1 \mathrm{~mm}$ ) and laminasets of mudstone with interlamina of sandstone and silty sandstone. Trace fossils include Planolites, Palaeophycus and Conichnus. There are rare beds $(<2 \mathrm{~cm})$ of plant detritus, predominantly fossil leaves (Neuropteris), and wood debris.
In the $\mathrm{H}_{1}$ facies, ripple form sets are preserved on the tops of $\mathrm{St}_{1}$ sandstone beds (Figure 3E, F). Eurypterid remains, and abundant coalified wood and plant debris are also present. In the $\mathrm{H}_{2}$ lithofacies, a low diversity, low abundance trace fossil suite is also preserved, which is interpreted as a highly stressed expression of the Cruziana Ichnofacies (Planolites, Palaeophycus, Conichnus (cf. Bann et al., 2004)).

These facies fill broad and flat-based, but steep-sided, linear topographic lows (Figure 4), and the vertical and lateral relationships of lithofacies in ICS lithosomes is generally consistent (Figure 5). In most exposures, lithofacies 1-7 compose, in some combination, clear-cut fining-upward successions in which conglomerates and/or sandstones pass upward into heterolithic facies (Figure 5).

\subsection{Interpretation of lithofacies}

Considering the nature of basal incisions, the geometry of ICS bodies, the unidirectional nature of flow within lithofacies $\mathrm{St}_{1}$ and $\mathrm{St}_{2}$, the predominance of fining-upward trends, and the overall abundance of heterolithic facies with depauperate brackish to marine traces the ICS is interpreted as a fluvial to estuarine deposit in incised paleochannels or paleovalleys. In this context, $\mathrm{Ci}_{\mathrm{b}}$ is interpreted as a lag formed on valley floors or channel bases above a basal incision surface. Some $\mathrm{Ci}_{h}$ units may also have formed in a similar setting, but others clearly formed by the disaggregation of large masses of fine-grained sediment produced by bank collapse (Figure 3G). Lithofacies $\mathrm{St}_{1}$ and $\mathrm{St}_{2}$ are interpreted to have formed through the migration of large and small dunes on the floors and bars of large, deep channels. The unidirectional paleocurrent distributions derived from these facies (southwest dominant paleoflows) indicate that sediments were deposited from unidirectional aqueous flows, and the low dispersion of paleocurrent data within individual bodies suggests that channels were of low sinuosity, consistent with confinement within incised margins. Furthermore, low-angle cross-bedded sandstones $\left(\mathrm{S}_{\mathrm{L}}\right)$ probably record the migration of bed waves under transitional (lower to upper) flow regime conditions (Figure 3D). The geometry of the cross-strata and their lateral transition into flat lamination locally are similar to structures described from modern alluvium (e.g., Fielding et al., 1999) and from a variety of ancient fluvial successions (Fielding, 2006).

Lithofacies $\mathrm{H}_{1}$ and $\mathrm{H}_{2}$ record low-energy current flow alternating with deposition from suspension. The unidirectional nature of ripple cross-lamination in these facies suggests a current-dominated environment, but the delicate interlamination of sandstone and mudstone (Figure 3E, F) also records frequent, short-term fluctuations in current activity. Although heterolithic facies are very common in coastal tidal environments (e.g., Reineck and Singh, 1986; Nio and Yang, 1991), they are not unique to such settings. Nevertheless, a tidal influence is suggested in the ICS by rhythmically interlaminated/interbedded sandstone/mudstone with ripple form sets on the upper surfaces of sandstone beds (Figure 3E, F) (cf. Reineck and Singh, 1986; Nio and Yang, 1991). Some level of marine or brackish influence on paleoenvironments is clearly indicated by the presence of fossil eurypterids (within the $\mathrm{H}_{1}$ Facies) and by the low-diversity Cruziana Ichnofacies trace assemblage (within the $\mathrm{H}_{2}$ Facies). The extremely low diversity and abundances in these fossil/trace fossil assemblages suggest some tidal influence (cf. Pemberton and Wightman, 1992; Gingras et al., 1999).

\subsection{Determination of facies associations}

Two distinct facies associations can be distinguished in ICS lithosomes (Figures 5 \& 6), particularly when genetic surfaces are recognized (Miall, 1985, 1988, 1992, 1994; Shanley and McCabe, 1994; Zaitlin et al., 1994; Feldman et al., 1995). Such 

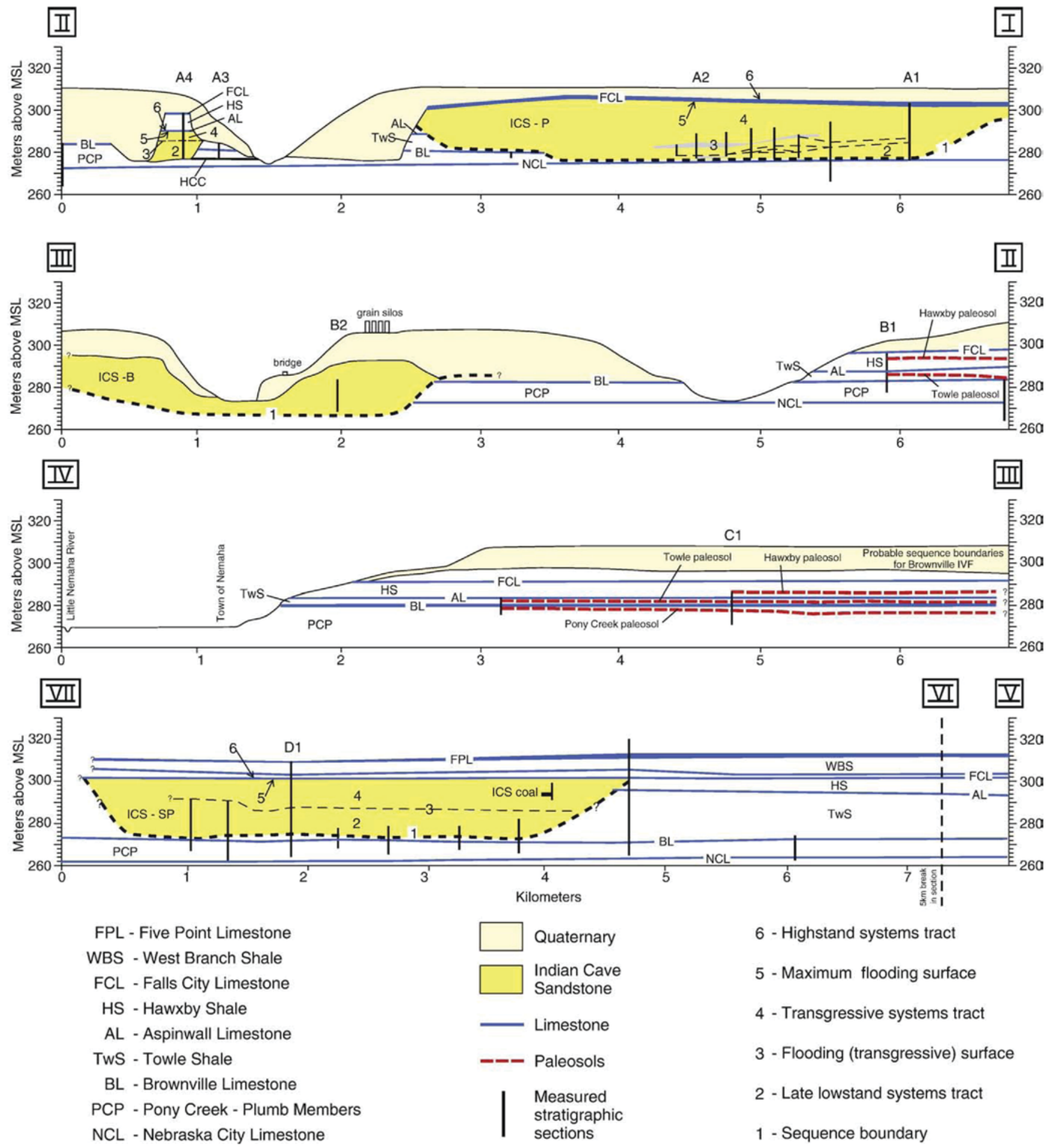

Figure 4. Geologic cross-sections: Peru to ICSP. Vertical black lines mark locations of measured sections shown on Figure 5. Peru (ICS-P), Honey Creek, Brownville (ICS-B) and ICSP (ICS-SP) ICS bodies shown in yellow. Honey Creek Coal (HCC) is present locally. Limestones shown in blue, paleosols in red, shales in white, Quaternary strata in light brown.

surfaces are identified here in hierarchical classification in which "first order" denotes surfaces of greatest lateral extent; "second order" denotes subordinate ones truncated against first order surfaces, and so on.

The basal Fluvial to Estuarine Facies Association overlies the basal incision surface (First Order Bounding Surface) and comprises multiple storeys, each separated from the next by a Third Order Bounding Surface. The Fluvial to Estuarine Facies Associa- tion is separated from the overlying Upper Estuarine Facies Association by a Second Order Bounding Surface (Figures 5 \& 6).

\subsubsection{Fluvial to Estuarine facies association (FE)}

The FE facies association comprises lithofacies $\mathrm{Ci}_{\mathrm{b}^{\prime}}, \mathrm{Ci}_{\mathrm{h}^{\prime}}, \mathrm{St}_{1^{\prime}}, \mathrm{St}_{2^{\prime}}$ $\mathrm{S}_{\mathrm{L}^{\prime}}$ and minor $\mathrm{H}_{1}$ (Figure 7). In the larger three lithosomes (Peru, Brownville and ICSP), a composite, multi-storey internal architecture is apparent, and storey boundaries are defined by ero- 
준

电

$$
\text { ๑1" }
$$

$\bar{z}$

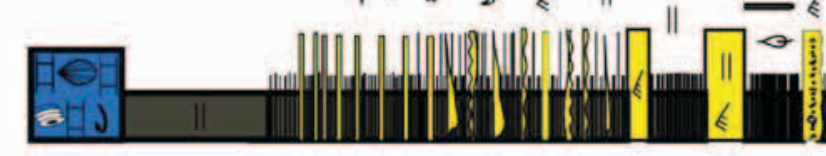

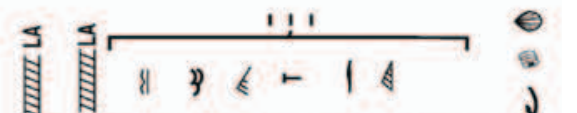

ปี

过
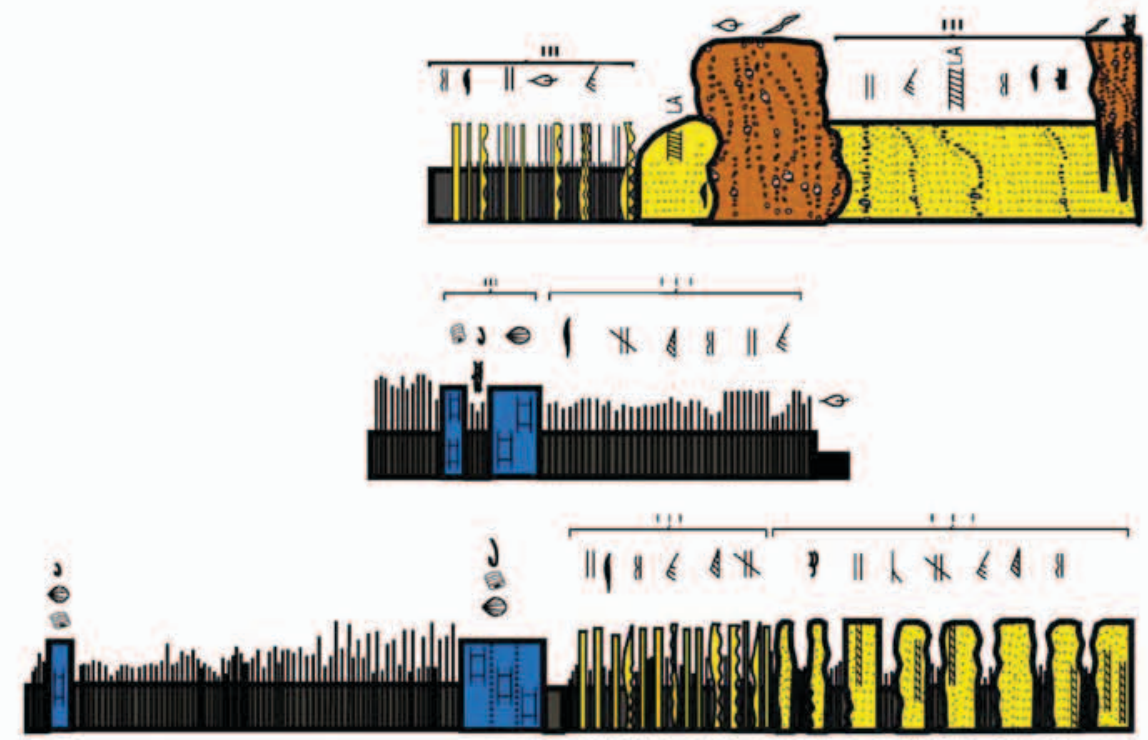

$\bar{\infty}$

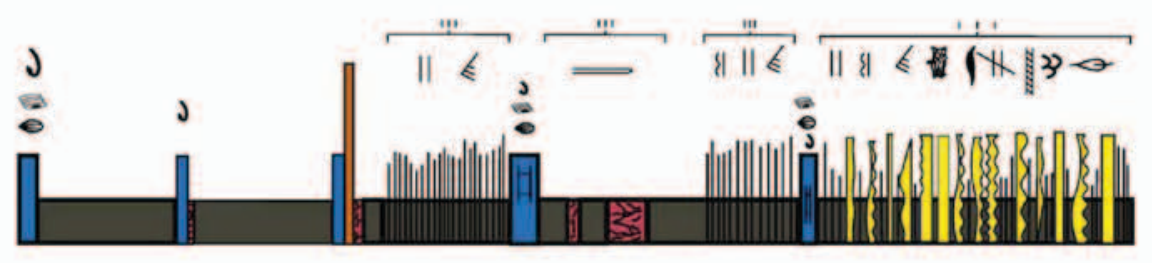

๓

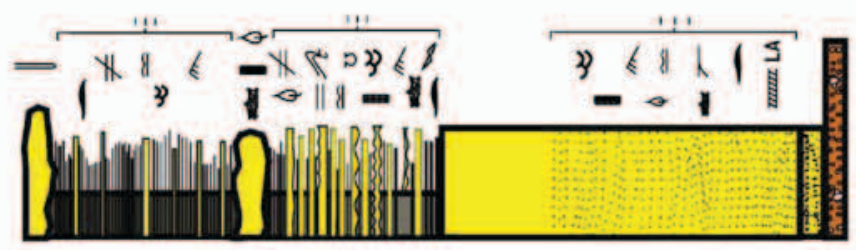

$\overline{0}$

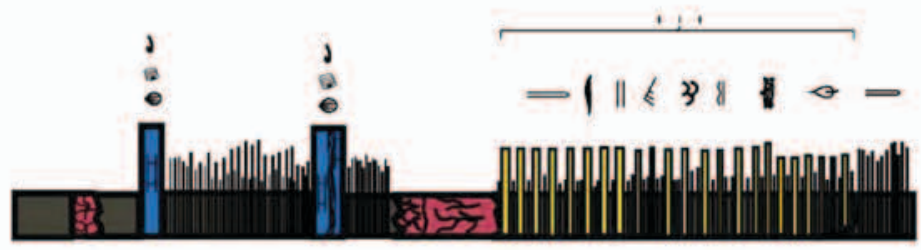

- $\quad$ - 


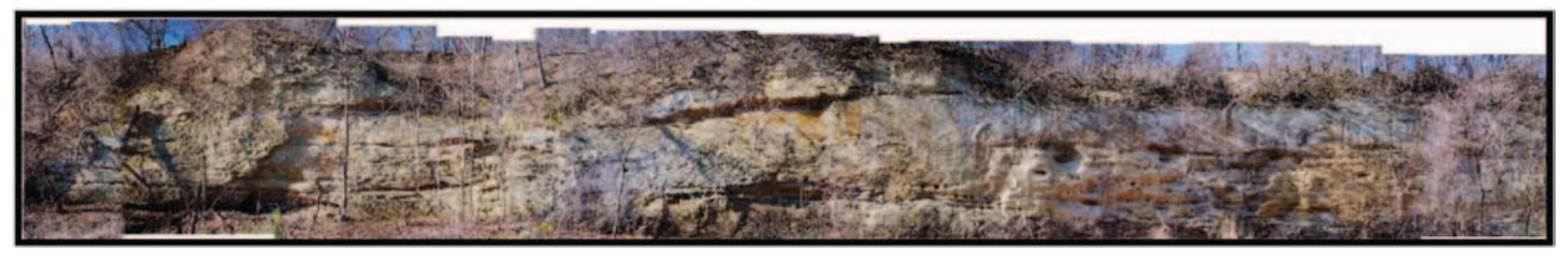

S

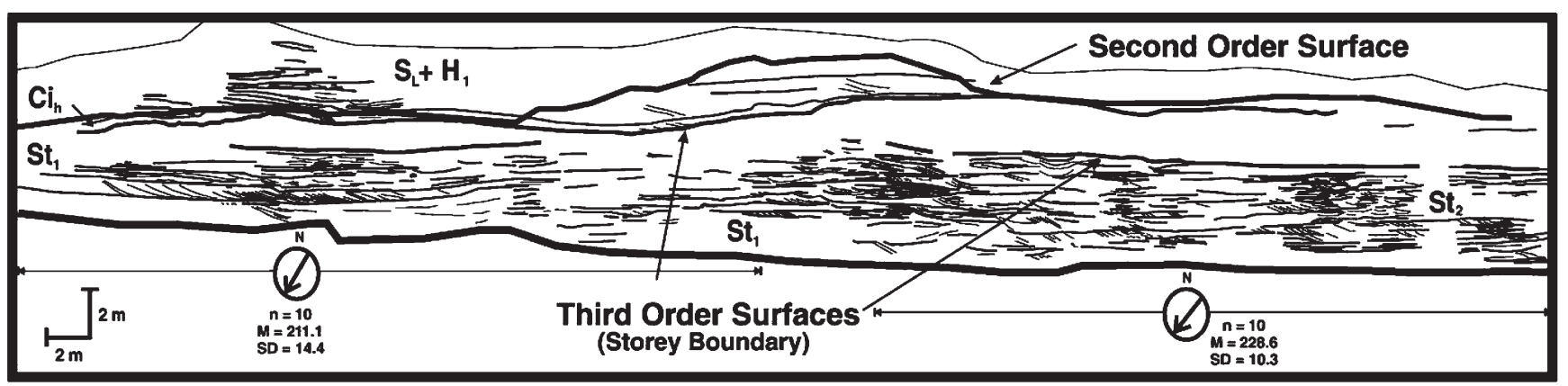

Figure 6. Indian Cave Sandstone at Peru (Figure 1B). First Order Bounding Surface (sequence boundary), defining the base of the ICS, is approximately $2 \mathrm{~m}$ below ground surface (see Figure 5: A1). Second Order Bounding Surface (transgressive surface) near top of the exposure separates Fluvial to Estuarine Facies Association from overlying Upper Estuarine Facies Association. Third Order Bounding Surfaces define storeys within lower unit. Mean paleocurrent directions shown by arrows within circles. See Figure 3 for facies codes.

sional surfaces with several meters of relief. In some cases, these third order bounding surfaces are overlain by $\mathrm{Ci}_{\mathrm{h}}$ (Figure 5). Typically, the lower portion of each storey above the basal conglomerate lags is dominated by $\mathrm{St}_{1}$, but $\mathrm{St}_{2}$ increases in abundance upward. In the few places where the inclination of major, internal (third order) bounding surfaces can be ascertained, the measured paleocurrent direction of these surfaces are coincident with those of other measured sedimentary structures in the same units and suggests that the dominant process of sediment accumulation was by downstream accretion on composite, mid-channel barforms. The multi-storey nature of the ICS bodies resulted either from repeated autocycles of channel incision and filling, or from an external forcing control (e.g., sea-level change).

The minor occurrence of $\mathrm{H}_{1}$ in this association indicates a subordinate tidal influence on the depositional environment. Mud drapes record counter-current flows and slack-water conditions, which we interpret as weak tidal inundation. We interpret tidal influence from the sandier heterolith variants (Figure 3E, F, H, I) on the basis of rhythmic lamination, localized lenticular and flaser bedding, and mudstone draped ripple foresets (Figure 3H, I) containing abundant organic debris (cf. Reineck and Singh, 1986; Nio and Yang, 1991; Van den Berg et al., 2007). Discontinuous lenses of heterolithic facies in the uppermost parts of trough fills and in other settings may indicate that tidal influence was more persistent, at least at times, but that its products were only infrequently preserved.

The preceding observations implicate deposition in the uppermost reaches of a fluvial-estuarine system (Figure 8) near the upstream terminus of the fluvial-tidal transition zone (Van den Berg et al., 2007) in which flows are overwhelmingly fluvial during peak discharge and neap tides, but in which a subordinate tidal inflow may also be produced during spring tides (cf. Nichols and Biggs, 1985; Dalrymple et al., 1992; Dalrymple and Choi, 2007; Van den Berg et al., 2007). This interpretation is entirely consistent with recent analyses of other Pennsylvanian incised valley fills (e.g., Feldman et al., 1995, 2005; Archer and Feldman, 1995; Bowen and Weimer, 2003) and with many other studies (e.g., Plink-Bjorklund, 2005; Greb and Martino, 2005).

\subsubsection{Upper Estuarine facies association (UE)}

The UE is dominated by $\mathrm{S}_{\mathrm{L}^{\prime}}, \mathrm{H}_{1}$ and $\mathrm{H}_{2}$ lithofacies (Figure 7). It typically overlies all of the cross-bedded sandstone-dominated storeys of the FE and forms the uppermost portions of the ICS bodies. Internal facies architecture is less clear-cut in the UE however, because outcrops of it are poor. UE typically has $\mathrm{S}_{\mathrm{L}}$ as basal units and passes upward into $\mathrm{H}_{2}$ facies with $\mathrm{S}_{\mathrm{L}}$ being restricted to lenses within it. The overall finer texture, dominance of the $\mathrm{H}_{2}$ lithofacies, and restricted trace fossil assemblage in this association suggests a diminished fluvial influence and a more tidal dominated environment. Therefore, UE is considered to represent a mud-dominated, tide-influenced, uppermost estuarine environment (Figure 8). This interpretation is consistent with studies of both modern and ancient environments (e.g., Dalrymple and Makino, 1989; Dalrymple et al., 1992, 1994; Tessier, 1993; Zaitlin et al., 1994; Tessier et al., 1995; Feldman et al., 1995, 2005; Archer and Feldman, 1995; Lanier and Tessier, 1998; Bowen and Weimer, 2003).

An overall transgressive trend is evident from the complete vertical succession of facies within each ICS body. The order of events revealed therein is: (1) incision of a linear topographic low, (2) deposition of sand in predominantly fluvial environments, and (3) progressive transition to more muddy and tideinfluenced settings over time (Figures $7 \& 8$ ). The ICS bodies are overlain by mudrocks or limestones that could be said to record the maximum extent of transgression in a cycle of relative sealevel fall and rise (Figure 7).

\section{Sequence stratigraphy}

The standing interpretation of the ICS as a constructional delta (Ossian, 1974) is clearly untenable in light of field observations and lithofacies analysis. Moreover, ICS sandstone bodies and their included genetic surfaces meet the criteria for stratigraphic sequences and sequence boundaries (Van Wagoner et al., 1988; Archer et al., 1994; Feldman et al., 1995; Heckel et al., 1998; Posamentier and Allen, 1999; Olszewski and Patzkowsky, 2003), and therefore they can be interpreted through the modern paradigm of sequence stratigraphy (Figures $4 \& 9$ ). ICS bodies 


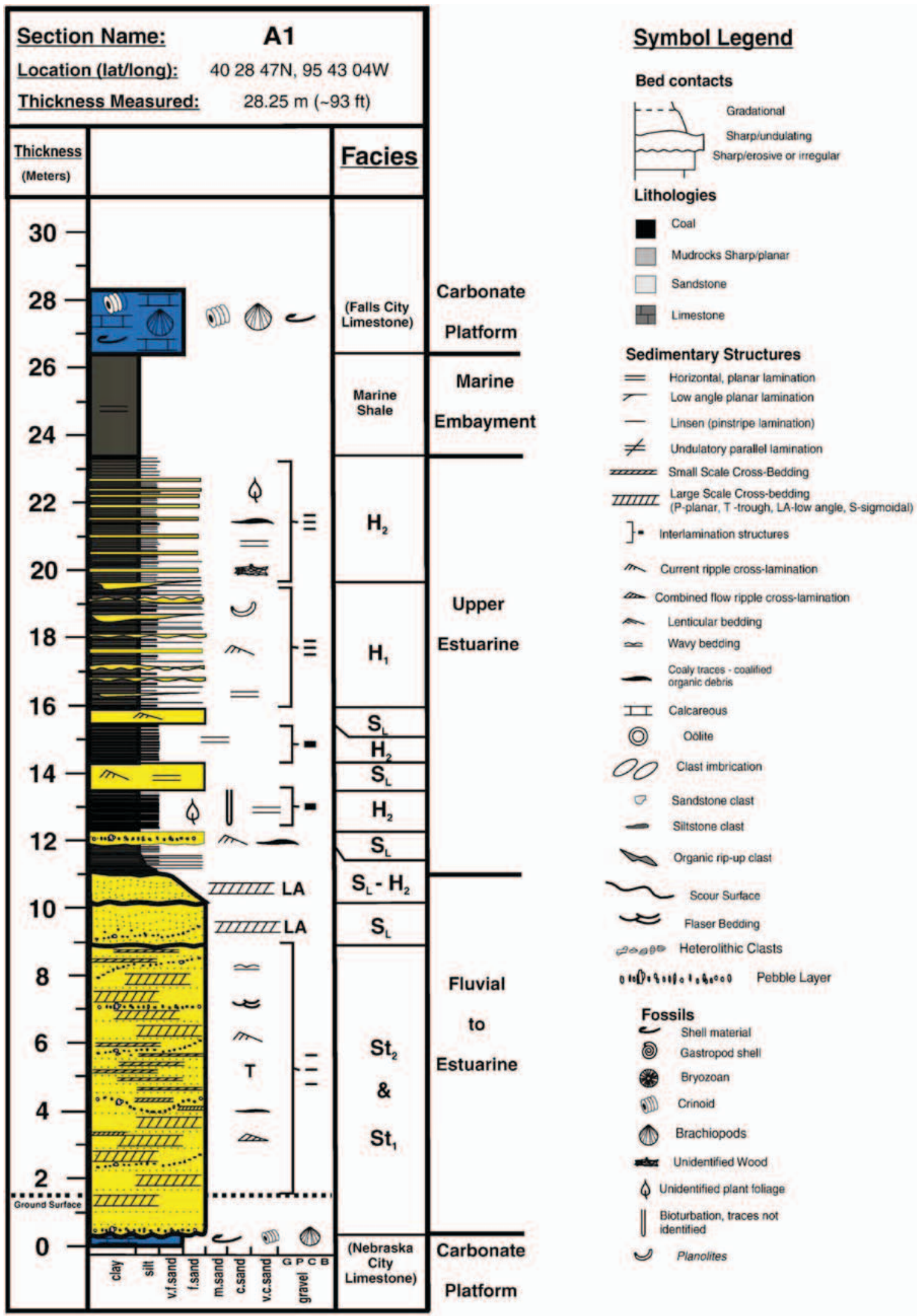

Figure 7. Graphic log of Indian Cave Sandstone from Peru locality A1.

at ICSP, Peru, and Honey Creek directly overlie marine strata, and their basal contacts are first-order surfaces marking abrupt marine-to-nonmarine basinward shifts in sedimentation. Within these bodies, fining-upward sequences are genetically-related stratigraphic units representing relatively continuous deposition through the fluvial-to-estuarine transition or fluvial-tidal transition zone (cf. Dalrymple et al., 1992, 1994; Shanley et al., 1992; Archer et al., 1994; Zaitlin et al., 1994; Feldman et al., 1995; 


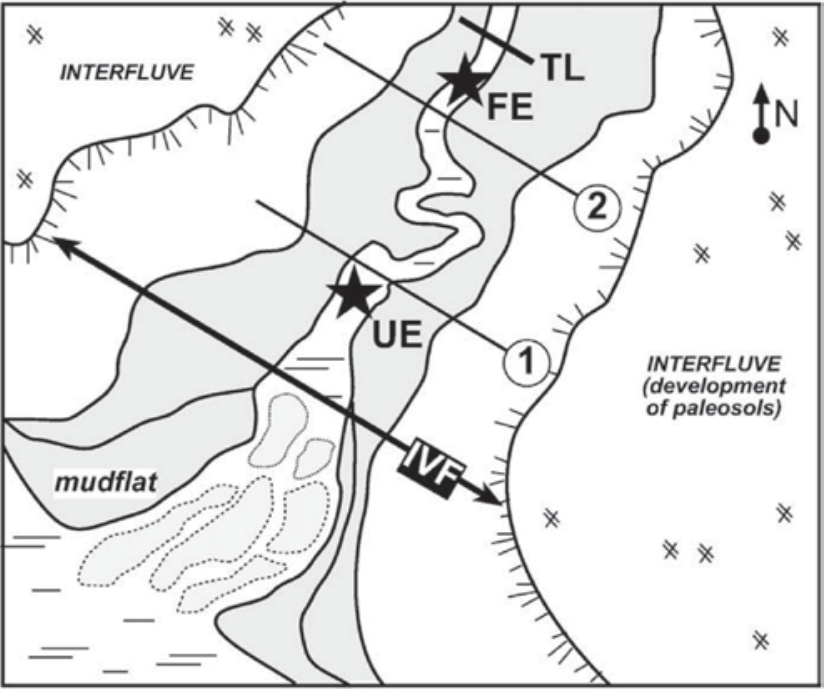

Figure 8. Positions (stars) of fluvial-to-estuarine (FE) and upper estuarine (UE) facies depicted on an idealized tidally dominated estuary (after Dalrymple et al., 1992). Facies assemblages are interpreted to be located either above (FE) or below (UE) "straight-meanderingstraight" section of estuarine funnel below tidal limit (TL).

Archer and Feldman, 1995; Posamentier and Allen, 1999; Van den Berg et al., 2007). The ICS exposures at ICSP, Peru, and Brownville are multistorey fills, very likely of incised valleys per se, but the smaller, single-storey Honey Creek sandstone body may be a tributary incised channel, although no direct connection with a larger system can be shown.
By applying the published interpretations of similar stratigraphic units (e.g., Joeckel, 1989, 1994, 1995, 1999; Dalrymple et al., 1992, 1994; Shanley et al., 1992; Archer et al., 1994; Zaitlin et al., 1994; Feldman et al., 1995; Blum and Price, 1998; Posamentier and Allen, 1999; Blum and Tornqvist, 2000) to field observations of the ICS and associated units, a progression of genetic events can readily be developed relative to sea-level change (Figure 9):

(1) Initially, falling relative sea level subaerially-exposed marine strata of the Wood Siding and Onaga Shale formations (cf. Moore, 1934; Heckel, 1980; Ross and Ross, 1985; Crowley and Baum, 1991; Soreghan and Giles, 1999; Isbell et al., 2003). Existing fluvial systems adjusted to lower relative sea level and incised broad valleys into these newly-emergent strata (Figure 4 and Figure 9). The lower stratigraphic position of the Honey Creek sandstone body relative to the Peru, Brownville, and ICSP bodies (Figures $2 \& 4$ ) however, records a separate episode of basal incision and fluvial sedimentation. Therefore, two sequences, formed during different transgressive-regressive cycles, are represented by the ICS sandstone bodies, contrary to the original implication of a single episode of sedimentation. Furthermore, the Honey Creek sandstone body is also smaller in cross-section and consists of but a single storey (Figure 4 and Figure 5: A3, A4), indicating that it formed under different conditions from the other bodies.

(2) Simultaneous with fluvial incision, paleosols developed on exposed interfluves between incised valleys and, we presume, regionally over the widespread exposure surface. Paleosols in the Towle Shale are correlated to the Honey Creek ICS body, and in the Hawxby Shale are correlated to the Peru, Brownville and ICSP bodies (Figures 4 \& 5: B1, C1). According to Posamentier and Allen (1999, pg 35), deposition during the

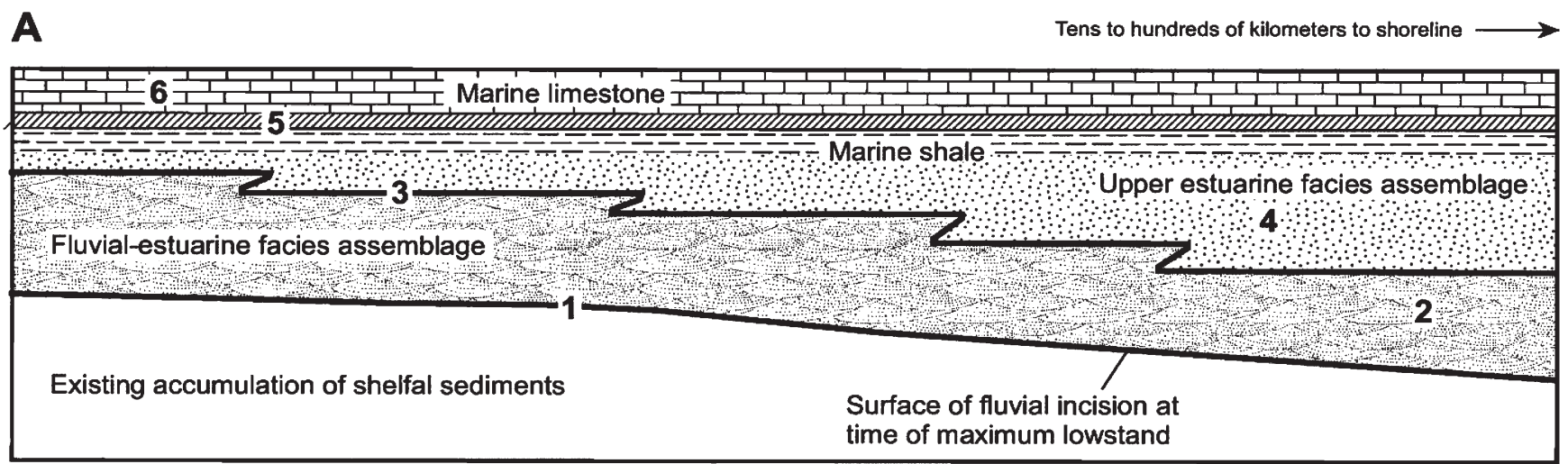

\section{B}

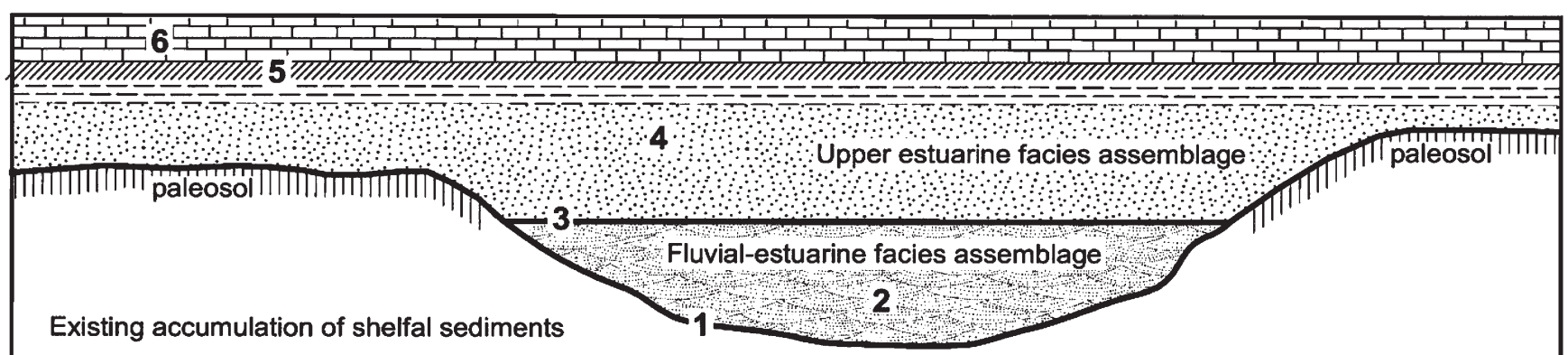

\section{1 - Sequence boundary \\ 2 - Late lowstand systems tract \\ 3 - Flooding (transgressive) surface \\ 4 - Transgressive systems tract}

5 - Maximum flooding surface

6 - Highstand systems tract

Figure 9. Sequence stratigraphic model for Indian Cave Sandstone (ICS) incised valley fills in high shelf, low gradient and low accommodations setting. Panel A: Longitudinal section through an idealized ICS IVF. Panel B: Cross-section through the same idealized IVF. 
late phase of the lowstand systems tract (LST) is characterized by several types of sedimentary systems including aggrading incised-valley fluvial fill. More specifically, during the late LST "fluvial late lowstand deposits unconformably overlie the sequence boundary within incised valleys" (Posamentier and Allen, 1999). Therefore, the basal portion of the ICS (Figures 4 \& 9) can be interpreted as late LST deposits (cf. Archer et al., 1994; Zaitlin et al., 1994; Archer and Feldman, 1995; Posamentier and Allen, 1999). Thus at this time in the depositional history of the ICS, the basal portions of the ICS (Figures 4 \& 9) were recognizable as late LST deposits (cf. Archer et al., 1994; Zaitlin et al., 1994; Archer and Feldman, 1995; Posamentier and Allen, 1999).

(3) Following Posamentier and Allen (1999), during the latest stages of relative sea-level fall or stillstand, grade-adjusted fluvial systems began to accumulate sediments atop the incision surfaces (Figures 4 \& 9), which are the underlying sequence boundaries. Fluvial storey boundaries, which developed as channels or valleys continued to fill with sediment, are interpreted architecturally as third-order bounding surfaces (Figure 6).

(4) Late LST deposition ends when relative sea level rises fast enough to overwhelm sediment supply and cause transgression to occur (Posamentier and Allen, 1999). Similarly, a continuing relative sea-level rise promoted an upward increase in tidally influenced sediments in the ICS channel or valley fills. These sea-level fluctuations likely influenced sedimentation far upstream from shoreline because of the low land-surface and fluvial gradients on the order of $10^{-1}$ to $10^{0} \mathrm{~m} / \mathrm{km}$, with structural dips $<0.15^{\circ}-0.25^{\circ}$ (cf. Heckel, 1977, 1980; Olszewski and Patzkowsky, 2003). ICS incised channels or valleys continued to fill with tidally-influenced fluvial strata until transgression advanced far enough inland to force a switch to upper-estuarine sedimentation and producing flooding surfaces (FS) between lower fluvial-to-estuarine fills and the upper-estuarine fills (Figures 4, 7, \& 9). Although it is likely that this change in sedimentation is gradual, the sedimentary record in the ICS lithosomes is seen as an abrupt transition from FE deposits to UE deposits. These flooding surfaces at the top of the late LSTs are the lower boundaries of the transgressive systems tracts or TSTs (Figure 4, 7, \& 9) of Dalrymple et al. (1992), Shanley et al. (1992), Archer et al. (1994), and Posamentier and Allen (1999), and they are interpreted architecturally as second order surfaces (Figure 6). We conclude that extremely low surface gradients and comparatively abrupt transgression prevented the deposition or preservation of middle and/or lower estuarine facies.

(5) The ICS fluvial-estuarine system represented by the Brownville, Peru, and ICSP bodies continued to be rapidly transgressed and became part of a broad marine embayment, in which bioturbated marine muds were deposited atop upper estuarine facies. Marine shales overlying the ICS sandstone bodies include the maximum flooding surface or MFS (Figure 4, 7, \& 9) of Dalrymple et al. (1992), Zaitlin et al. (1994), and Posamentier and Allen (1999).

(6) The deposition of terrigenous sediment was eventually moved far landward, and a carbonate platform environment (Figure 4, 7, \& 9) developed as the highstand systems tract or HST (cf. Shanley et al., 1992; Archer et al., 1994; Shanley and McCabe, 1994; Posamentier and Allen, 1999).

The large sizes and complex architecture of ICS sandstone bodies at Peru, Brownville, and ICSP prompts us to interpret them as incised valley fills (IVFs), rather than single incised channels. Many Pennsylvanian IVFs have been described in North America (Aitken and Flint, 1994; Archer et al., 1994; Gib- ling and Bird, 1994; Kvale and Barnhill, 1994; Archer and Feldman, 1995; Feldman et al., 1995; Heckel et al., 1998; Bowen and Weimer, 2003, 2004). The variable stratal composition and expression of these IVFs are to be expected because facies preservation in an estuarine system is a complex mechanism that depends on many interrelated factors (Dalrymple et al., 1992, 1994). Despite significant differences between individual IVFs, though, all of these examples share: (1) underlying, easily-recognizable sequence boundaries in the form of basal incision surfaces produced by falls in relative sea level; and (2) fluvial-toestuarine sediments, which filled the resulting accommodation space during subsequent rises in sea level.

Some Pennsylvanian IVFs are complex, composite features and paleosols are absent on the associated interfluves (Bowen and Weimer, 2003, 2004), unlike the ICS. In others, outer and middle estuary facies are well-characterized. In these examples, also unlike the ICS, estuarine mouth bars, tidal sand bars, extensive tidal rhythmites, bayhead deltas, shelly ravinement surfaces and a diverse array of trace fossils are preserved (Kvale and Barnhill, 1994; Archer et al., 1994; Archer and Feldman, 1995; Feldman et al., 1995; Bowen and Weimer, 2003).

\section{Discussion}

The relative abundance of Pennsylvanian IVFs in North America reflects frequent fluctuations in relative sea-level, punctuated episodes of subaerial exposure, and the development of incised fluvial systems during periods of low sea level, all of which are consistent with eustatic sea-level change. The ICS sandstone bodies in particular reflect significant changes in sealevel because there are at least four IVFs, of at least two different ages, in only 30-40 m of stratigraphic section. The timeframes associated with these events remain conjectural.

Recently, Wardlaw et al. (2004) proposed that the stratigraphic interval containing the ICS bodies represent a Gzhelian third-order sequence composed of three fourth-order sequences (Brownville, Falls City, and Five Point sequences). They also interpret a fifth-order sea level curve from widespread subaerial exposure surfaces and paleosols in the Pony Creek Shale, Towle Shale, West Branch Shale and Hamlin Shale (Figure 10). Additionally, Olszewski and Patzkowsky (2003) interpret areallyextensive paleosols as evidence for bounding surfaces within composite fourth order sequences. Two of Olszewski and Patzkowsky's (2003) fourth order composite sequences include the Richardson Composite Sequence (Dover Limestone through Aspinwall Limestone) and the Falls City/Five Point Composite Sequence (Aspinwall Limestone through the Hamlin Shale). Within each composite sequence, certain regional paleosol surfaces correlate to incised valley fills (in Kansas) and define a class of fifth-order cycles (Olszewski and Patzkowsky, 2003).

The sequence stratigraphic interpretation of Wardlaw et al. (2004) and Olszewski and Patzkowsky (2003) establishes an ordered hierarchy of the Upper Pennsylvanian-Lower Permian stratigraphy of the Midcontinent. In their interpretations, as well as those of other authors (Joeckel, 1991, 1994, 1999; Miller and West, 1993; Heckel et al., 1998) widespread paleosols are evidence for emergence and prolonged subaerial exposure. Paleosols identified as fifth order sequence boundaries by both Olszewski and Patzkowsky (2003) and Wardlaw et al. (2004) correlate to the position of paleosols in this study. In this investigation, paleosols in the Towle and Hawxby shale members are interpreted to correlate as the remnants of the exposed interfluves of the associated incised valleys (Figures 4 \& 10A). Because Wardlaw et al. (2004) utilize a more refined terminology with respect to the categorization of stratigraphic posi- 
A

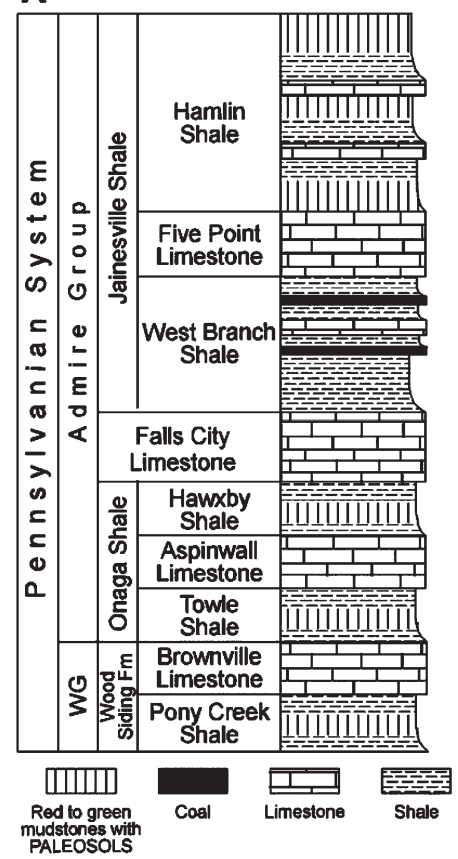

B

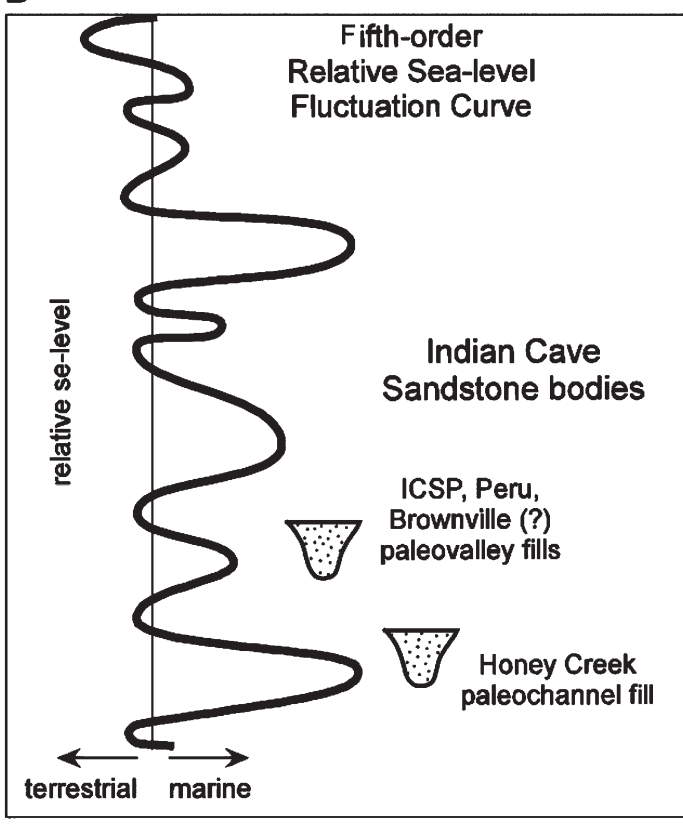

C

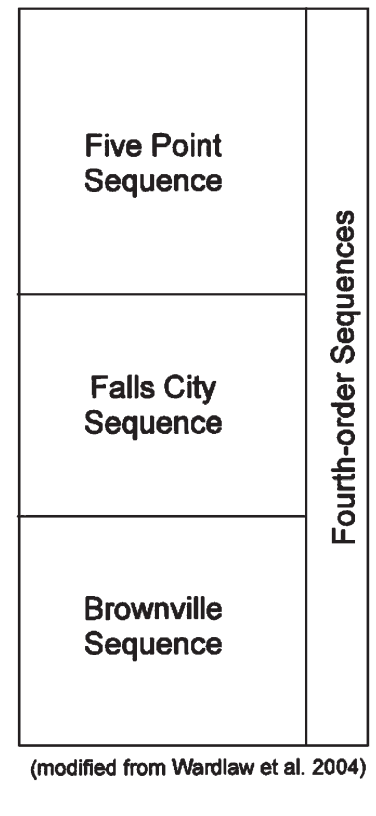

Figure 10. Correlation of sequences recognized in this study with those of Wardlaw et al. (2004). Sequence boundary at base of Indian Cave and Peru bodies corresponds to paleosol within Hawxby Shale (Figure 9A); base of Honey Creek body correlates to paleosol within Towle Shale (Figure 9A). Correlation of Brownville ICS body is tentative. Wardlaw et al. (2004) define paleosols as high-frequency, fifth-order sequence boundaries (Figure 9B). Using the Wardlaw et al. (2004) scheme, Peru, Brownville and ICSP IVFs correspond to the fourth-order Falls City Sequence (Figure 9C), and the Honey Creek incised channel fill corresponds to fourth-order Brownville Sequence (Figure 9C).

tion (as compared to that of Olszewski and Patzkowsky, 2003), their terms (Figure 10B, C) are used herein to make the following correlations between this investigation and their work as follows: the Honey Creek ICS body corresponds to a fifth order sequence found within the fourth order Brownville Sequence of the third order Gzhelian Late Highstand Sequence. The ICSP and Peru ICS bodies correspond to a fifth order sequence found within the fourth order Falls City Sequence of the third order Gzhelian Late Highstand Sequence (Figure 10B, C). The stratigraphic position of the upper and lower contacts of the Brownville ICS body are currently unknown, however, it is known that the Brownville body is younger than the Brownville sequence, as it occupies the stratigraphic position of both the Brownville and Aspinwall limestones. This stratigraphic position would make it at least equivalent to the fifth-order sequence found in the fourth-order Falls City Sequence, or possibly younger.

The inferred magnitude of paleo-sea-level drawdown from the ICS bodies can be used to help constrain potential eustatic sea-level fluctuations during the latest Pennsylvanian, which in turn contributes to a better understanding of global environmental change during the late Paleozoic Ice Age. A recent compilation of estimates of eustatic sea-level change for the Carboniferous and Permian systems by Rygel et al. (2008) highlights a prominent inconsistency for the late Pennsylvanian, whereby evidence from valley fill and other terrigenous clastic facies assemblages indicates much smaller fluctuations $(<40 \mathrm{~m})$ than do models and geochemical proxies $(<150 \mathrm{~m})$. Resolving this disparity is important in order to assess the hypothesis of some workers (e.g., Montañez et al., 2007) that the late Pennsylvanian was an interval of relatively benign climate mode separating two intervals of severe Icehouse climate. The modest estimates of sea-level drawdown derived herein from the ICS are consistent with other estimates from this time period derived from similar sources, and inconsistent with model and proxy predictions, lending weight to the notion that eustatic sea-level fluctuations were relatively subdued during the Late Pennsylvanian.

\section{Conclusions}

Contrary to nearly a century of geologic interpretation and stratigraphic nomenclature, we conclude that the "Indian Cave Sandstone" is neither a single lithostratigraphic unit, nor is it an association of separate channel- or valley-fills of the same age and related to exactly the same events. Rather, the name has been applied to at least four distinct incised channel/valley fills of at least two different ages, and together these fills record a far more complicated history of sea-level change and depositional-system response than was previously assumed. The term "Indian Cave Sandstone," in its historical usage, can only be equated to an allostratigraphic unit (North American Commission on Stratigraphic Nomenclature, 1983). These realizations have great heuristic value in the study and interpretation of many other (Figures 4, 7, \& 9) sandstone bodies.

Rather than representing a constructive delta deposit (Ossian, 1974) or a sandstone channel fill with coeval mudrocks as lateral equivalents (Barbour, 1914), the ICS consists of fluvialto-estuarine (late lowstand systems tract) and upper estuarine (transgressive systems tract) facies assemblages filling incised channels or valleys with basal incision surfaces that are also first-order bounding surfaces. The strong fluvial motif in the ICS indicates high-discharge flow from a large drainage basin on the exposed continental interior to the north and east. Unlike some analogous deposits, middle-estuarine facies are conspicuously absent in the ICS. The upper estuarine facies association lies between two second-order (i.e., flooding) surfaces, one at the top of the FE facies assemblage representing the transgressive surface (TS), and one at the bottom of the nearshore-marine shales. The uppermost contact of the aforementioned shales, in turn, represents the maximum flooding surface (MFS), and above that the shallow-marine limestone (Falls City Limestone) represents the highstand systems tract (HST). Identification of this shallowmarine limestone as the highstand system tract is a significant departure from the most widely-cited model for Midcontinent 
Pennsylvanian cyclothems (Heckel, 1980), in which black phosphatic shales are taken to represent maximum sea-level depths.

Perhaps most importantly, the ICS IVFs are particularly valuable in interpreting Pennsylvanian sea-level change and the response of terrigenous depositional systems. Accommodation space on the Pennsylvanian northern Midcontinent shelf was limited by passive subsidence and eustatic sea-level change. ICS sandstone bodies are laterally correlative only with interfluve exposure surfaces and paleosols in the Towle and Hawxby shales, leading to the conclusion that the minimum sea-level change required to produce the deepest ICS IVF is equivalent to the maximum thickness of that fill, or approximately $30 \mathrm{~m}$. This estimate is half or less of the magnitude proposed by certain studies of Pennsylvanian strata (Heckel, 1980, 1986, 1994, 2002; Ross and Ross, 1985; Adlis et al., 1988; Soreghan and Giles, 1999). Such a quantifiable local estimation of relative sea-level change is only possible because incised valley fills can be identified, and then interpreted within a sequence stratigraphic framework. If such estimates can be so readily made from Pennsylvanian IVFs, it should be possible to more accurately constrain magnitudes of eustatic sea-level fluctuation during the late Paleozoic Gondwanan Ice Age.

\section{Acknowledgments}

We would like to thank G.J. Weltje, M.E. Donselaar and an anonymous referee for Sedimentary Geology for their review and suggestions on improving this manuscript. Their efforts significantly enhanced the quality of this paper.

The following organizations and individuals are gratefully recognized for their help and support: University of Nebraska Department of Geosciences, University of Nebraska School of Natural Resources Conservation and Survey Division, Lincoln Gem and Mineral Club, Nebraska Public Power District Cooper Nuclear Generating Station, Nemaha Natural Resources District, Nebraska Game and Parks Commission, R. Pabian, T. Morrison, J. Swigart, Mr. and Mrs. E. Duerfeldt, R. Kuhn, C. Reeves, Mr. and Mrs. R. Hayek, and numerous other private property owners.

\section{References}

Adlis et al., 1988 D. S. Adlis, E. L. Grossma, T. E. Yancey, and R. D. McLerran, Isotope stratigraphy and paleodepth changes of Pennsylvanian cyclical sedimentary deposits, Palaios 3 (1988), pp. 487-506.

Aitken and Flint, $1994-$ J. F. Aitken and S. S. Flint, High frequency sequences and the nature of incised-valley fills in fluvial systems of the Breathitt Group (Pennsylvanian), Appalachian Foreland Basin, Eastern, Kentucky. In: R. W. Dalrymple, R. Boyd and B. A. Zaitlin, Editors, Incised-valley systems: Origin and Sedimentary Sequences, SEPM Special Publication vol. 51 (1994), pp. 353-368.

Archer and Feldman, 1995 A. W. Archer and H. R. Feldman, Incised valleys and estuarine facies of the Douglas Group (Virgilian): implications for similar Pennsylvanian sequences in the U. S. Mid-Continent. In: N. Hyne, Editor, Sequence stratigraphy of the Mid-Continent, Tulsa Geol. Soc., Tulsa, OK (1995), pp. 119-140.

Archer et al., 1994 A. W. Archer, W. P. Lanier, and H. R. Feldman, Stratigraphy and depositional history within incised-paleovalley fills and related facies, Douglas Group (Missourian/Virgilian; Upper Carboniferous) of Kansas, USA. In: R. W. Dalrymple, R. Boyd and B. A. Zaitlin, Editors, Incised-valley systems: Origin and Sedimentary Sequences, SEPM Spec. Pub. vol. 51 (1994), pp. 353-368.

Baars et al., 1994a D. L. Baars, C. A. Ross, S. M. Ritter, and C. G. Maples, Proposed repositioning of the Pennsylvanian-Permian boundary in Kansas, Kansas Geol. Surv. Bull. 230 (1994), pp. 5-10.

Baars et al., 1994b $\rightarrow$ D. L. Baars, S. M. Ritter, C. G. Maples, and C. A. Ross, Redefinition of the Upper Pennsylvanian Virgilian series in Kansas, Kansas Geol. Surv. Bull. 230 (1994), pp. 11-16.

Bann et al., $2004-$ K. L. Bann, C. R. Fielding, J. A. MacEachern, and S. C. Tye, Differentiation of estuarine and offshore marine deposits using integrated ichnology and sedimentology; Permian Pebbley Beach Formation, Sydney Basin, Australia. In: D. McIlroy, Editor, The Application of Ichnology to Palaeoenvironmental and Stratigraphic Analysis, Geological Society of London, Special Publication vol. 228 (2004), pp. 179-211.

Barbour, 1914 E. H. Barbour, Eurypterid beds of Nebraska with notice of new species, Eurypterus nebraskensis, Nebraska Geol. Surv. Rep. 34 (1914), pp. 193-203.

Blum and Price, 1998 M. D. Blum and D. M. Price, Quaternary alluvial plain construction in response to interacting glacio-eustatic and climatic controls,
Texas Gulf Coastal Plain. In: K. Shanley and P. McCabe, Editors, Relative Role of Eustasy, Climate, and Tectonism in Continental Rocks, Society for Sedimentary Geology (SEPM) Special Publication vol. 59 (1998), pp. 31-48.

Blum and Tornqvist, $2000-$ M. D. Blum and T. E. Tornqvist, Fluvial responses to climate and sea-level change: a review and look forward, Sedimentology 47 (2000), pp. 2-48.

Bowen and Weimer, $2003 \rightarrow$ D. W. Bowen and P. Weimer, Regional sequence stratigraphic setting and reservoir geology of Morrow incised-valley sandstones (lower Pennsylvanian), eastern Colorado and western Kansas, Am. Assoc. Petrol. Geol. Bull. 87 (2003), pp. 781-815.

Bowen and Weimer, 2004 D. W. Bowen and P. Weimer, Reservoir geology of Nicolas and Liverpool cemetery fields (Lower Pennsylvanian), Stanton County Kansas, and their significance to regional interpretation of Morrow Formation incised-valley-fill systems in eastern Colorado and western Kansas, Am. Assoc. Petrol. Geol. Bull. 88 (2004), pp. 47-70.

Burchett, $1977 \longrightarrow$ R. R. Burchett, Coal resources of Nebraska, Nebraska Geologic Survey Resource Report 8 (1977), pp. 1-185.

Campbell et al., 1988 J. A. Campbell, C. J. Mankin, A. B. Schwarzkopf, and J. H. Raymer, Habitat of petroleum in Permian rocks of the midcontinent region. In: W. A. Morgan and J. A. Babcock, Editors, Permian Rocks of the Midcontinent, Midcontinent, SEPM Spec. Pub. vol. 1 (1988), pp. 13-35.

Crowley and Baum, 1991 T. J. Crowley and S. K. Baum, Estimating Carboniferous sea-level fluctuations from Gondwanan ice extent, Geology 19 (1991) pp. 975-977.

Dalrymple and Choi, 2007 R. W. Dalrymple and K. Choi, Morphologic and facies trends through the fluvial-marine transition in tide-dominated depositional systems: a schematic framework for environmental and sequencestratigraphic interpretation, Earth-Sci. Rev. 81 (2007), pp. 135-174.

Dalrymple and Makino, 1989 R. W. Dalrymple and Y. Makino, Description and genesis of tidal bedding in the Cobequid Bay-Salmon River Estuary, Bay of Fundy, Canada. In: A. Taira and F. Masuda, Editors, Sedimentary Facies in the Active Plate Margin, Terra Scientific Publishing Company, Tokyo (1989), pp. 151-177.

Dalrymple et al., $1992>$ R. W. Dalrymple, B. A. Zaitlin, and R. Boyd, Estuarine facies models: conceptual basis and stratigraphic implications, J. Sediment. Petrol. 62 (1992), pp. 1130-1146.

Dalrymple et al., 1994 R. W. Dalrymple, R. Boyd, and B. A. Zaitlin, History of research, types and internal organization of incised valley systems: introduction to the volume. In: R. W. Dalrymple, R. Boyd and B. A. Zaitlin, Editors, Incised-Valley Systems: Origin and Sedimentary Sequences, SEPM Spec. Publ. vol. 51, SEPM, Tulsa (1994), pp. 1-10.

Davydov et al., $1998 \rightarrow$ V. I. Davydov, B. F. Glenister, C. Spinosa, S. M. Ritter, V. V. Chernkh, B. R. Wardlaw, and W. S. Snyder, Proposal of Aidaralash as Global Stratotype Section and Point (GSSP) for base of the Permian System, Episodes 21 (1998), pp. 11-18.

Feldman et al., 1995 H. R. Feldman, M. R. Gibling, A. W. Archer, W. G. Wightman, and W. P. Lanier, Stratigraphic architecture of the Tonganoxie paleovalley fill (Lower Virgilian) in northeastern Kansas, Am. Assoc. Petrol. Geol. Bull. 79 (1995), pp. 1019-1043.

Feldman et al., 2005 H. R. Feldman, E. K. Franseen, R. M. Joeckel, and P. H. Heckel, Impact of longer term climate shifts on architecture of high-frequency sequences (Cyclothems), Pennsylvanian of Midcontinent, U. S. A., J. Sediment. Res. 75 (2005), pp. 350-368.

Ferm, 1974 J. C. Ferm, Carboniferous environmental models in the eastern United States and their significance. In: G. Briggs, Editor, Carboniferous of the southeastern United States, Geol. Soc. Am. Spec. Pap. vol. 148 (1974), pp. 79-95.

Fielding, 2006 C. R. Fielding, Upper flow regime sheets, lenses and scour fills: extending the range of architectural elements for fluvial sediment bodies, Sediment. Geol. 190 (2006), pp. 227-240.

Fielding et al., $1999 \rightarrow$ C. R. Fielding, J. Alexander, and R. McDonald, Sedimentary facies from GPR surveys of the modern, upper Burdekin River of north Queensland, Australia: consequences of extreme discharge fluctuations. In: N. D. Smith and J. Rogers, Editors, Fluvial Sedimentology VI, Int. Assoc. Sedimentologists Spec. Pub. vol. 28 (1999), pp. 347-362.

Fischbein, $2006 \checkmark$ S. A. Fischbein, Lithofacies, Architecture and Sequence Stratigraphic Interpretation of the Upper Pennsylvanian Indian Cave Sandstone, Northern Midcontinent Shelf, U. S. A. (southeastern Nebraska). Ph. D. thesis, 2006, University of Nebraska-Lincoln, Lincoln, Nebraska; http://digitalcommons.unl.edu/geoscidiss/

Gibling and Bird, $1994 \longrightarrow$ M. R. Gibling and D. J. Bird, Late Carboniferous cyclothems and alluvial paleovalleys in the Sydney basin, Nova Scotia, Geol. Soc. Am. Bull. 106 (1994), pp. 105-117.

Gingras et al., 1999 M. K. Gingras, S. G. Pemberton, and T. Saunders, The ichnology of modern and Pleistocene brackish-water deposits at Willapa Bay, Washington: variability in estuarine settings, Palaios 14 (1999), pp. 352-374.

Greb and Martino, $2005>$ S. F. Greb and R. L. Martino, Fluvial-estuarine transitions in fluvial-dominated successions: examples from the Lower Pennsylvanian of the Central Appalachian Basin. In: M. D. Blum, S. B. Marriott and S. F. Leclair, Editors, Fluvial Sedimentology VII, Int. Assoc. Sedimentologists, Spec. Pub. vol. 35 (2005), pp. 425-451.

Heckel, 1977 P. H. Heckel, Origin of phosphatic black shale facies in Pennsylvanian cyclothems of the mid-continent North America, Am. Assoc. Petrol. Geol. Bull. 61 (1977), pp. 1045-1068.

Heckel, $1980>$ P. H. Heckel, Paleogeography of eustatic model for deposition of Midcontinent Upper Pennsylvanian cyclothems. In: T. D. Fouch and E. R. Magathan, Editors, Paleozoic Paleogeography of the West-Central United States, Rocky Mountain Paleogeography Symposium vol. 1, SEPM, Tulsa (1980), pp. 197-215. 
Heckel, 1986 P. H. Heckel, Sea-level curve for Pennsylvanian eustatic marine transgressive-regressive depositional cycles along Midcontinent outcrop belt, North America, Geology 14 (1986), pp. 330-334.

Heckel, 1994 P. H. Heckel, Evaluation of evidence for glacio-eustatic control over marine Pennsylvanian cyclothems in North America and consideration of possible tectonic effects, SEPM Concepts in Sedimentology and Paleontology vol. 4 (1994), pp. 65-87.

Heckel, 2002 P. H. Heckel, Overview of Pennsylvanian cyclothems in Midcontinent North America and brief summary of those elsewhere in the world. In: L. V. Hills, C. M. Henderson and E. W. Bamber, Editors, Carboniferous and Permian of the World: XIV ICCP Proceedings, Canadian Society of Petroleum Geologists Memoir vol. 19, Can. Soc. Petrol. Geol., Calgary (2002), pp. 79-98.

Heckel et al., 1998 P. H. Heckel, M. R. Gibling and N. R. King, Stratigraphic model for glacial-eustatic Pennsylvanian cyclothems in highstand nearshore detrital regimes, J. Geol. 106 (1998), pp. 373-383.

Horne and Ferm, $1974-$ J. C. Horne and J. C. Ferm, Depositional model for the Mississippian-Pennsylvanian boundary in northeastern Kentucky. In: G. Briggs, Editor, Carboniferous of the Southeastern United States, Geol. Soc. Am. Spec. Pap. vol. 148 (1974), pp. 97-114.

Isbell et al., 2003 J. L. Isbell, M. F. Miller, K. L. Wolfe and P. A. Lenaker, Timing of late Paleozoic glaciation in Gondwana: was glaciation responsible for the development of northern hemisphere cyclothems?. In: M. A. Chan and A. A. Archer, Editors, Extreme Depositional Environments; Mega End-Members in Geologic Time, Geol. Soc. Am. Spec. Pap. vol. 370 (2003), pp. 5-24.

Joeckel, 1989 R. M. Joeckel, Geomorphology of a Pennsylvanian land surface: pedogenesis in the Rock Lake Shale Member, southeastern Nebraska, J. Sediment. Petrol. 59 (1989), pp. 469-481.

Joeckel, 1991 R. M. Joeckel, Paleosol stratigraphy of the Eskridge Formation; Early Permian pedogenesis and climate in southeastern Nebraska, Journal of Sedimentary Petrology 61 (2) (1991), pp. 234-255

Joeckel, $1994-R$. M. Joeckel, Virgilian (Upper Pennsylvanian) paleosols in the upper Lawrence Formation (Douglas Group) and in the Snyderville Shale Member (Oread Formation, Shawnee Group) of the northern midcontinent, USA: pedologic contrasts in a cyclothem sequence, J. Sediment. Petrol. 64 (1994), pp. 853-866.

Joeckel, $1995 \rightarrow$ R. M. Joeckel, Paleosols below the Ames marine unit (Upper Pennsylvanian Conemaugh Group) in the Appalachian Basin, USA: variability on an ancient depositional landscape, J. Sediment. Res. 65 (2) (1995), pp. 393-407.

Joeckel, 1999 R. M. Joeckel, Paleosol in the Galesburg Formation (Kansas City Group, Upper Pennsylvanian) northern midcontinent, USA: evidence for climate change and mechanisms of marine transgression, J. Sediment. Res. 69 (1999), pp. 720-737.

Kvale and Barnhill, 1994 E. P. Kvale and M. L. Barnhill, Evolution of Lower Pennsylvanian estuarine facies within two adjacent paleovalleys, Illinois Basin, Indiana. In: R. W. Dalrymple, R. Boyd and B. A. Zaitlin, Editors, Incised-Valley Systems: Origin and Sedimentary Sequences, SEPM Spec. Publ. vol. 51, SEPM, Tulsa (1994), pp. 191-207.

Lanier and Tessier, $1998 \rightarrow$ W. P. Lanier and B. Tessier, Climbing ripple bedding in the fluvio-estuarine transition: a common feature associated with tidal dynamics (modern and ancient analogues). In: C. R. Alexander, R. A. Davis and V. J. Henry, Editors, Tidalites: Processes and Products, SEPM Special Publication vol. 61, SEPM, Tulsa (1998), pp. 109-117.

Leclair and Bridge, $2001 \checkmark$ S. F. Leclair and J. S. Bridge, Quantitative interpretation of sedimentary structures formed by river dunes, J. Sediment. Res. 71 (2001), pp. 713-716.

Mazzullo et al., 2005 S. J. Mazzullo, T. McHenry, T. Sanders, C. Teal-Mazzullo, B. Wilhite and M. Wilhite, Outcrop of the Indian Cave Sandstone (Lower Permian) in Greenwood County, Kansas, Kansas Geol. Soc. Bull. 80 (2005), pp. 12-20.

McKee and Crosby, 1975 E. D. McKee and E. J. Crosby, Paleotectonic investigations of the Pennsylvanian System in the United States, U. S. Geol. Surv. Spec. Pap. vol. 853 (1975).

Miall, 1985 A. D. Miall, Architectural element analysis: a new method of facies analysis applied to fluvial deposits, Earth Science Reviews 22 (1985), pp. 261-308.

Miall, 1988 A. D. Miall, Architectural elements and bounding surfaces in fluvial deposits: anatomy of the Kayenta Formation (Lower Jurassic), southwest Colorado, Sedimentary Geology 55 (1988), pp. 233-262.

Miall, 1992 A. D. Miall, Alluvial deposits. In: R. G. Walker and N. P. James, Editors, Facies models: response to sea-level change, Geological Society of Canada (1992), pp. 119-142.

Miall, 1994 A. D. Miall, Reconstructing fluvial macroform architecture from twodimensional outcrops: examples from the Castlegate Sandstone, Book Cliffs, Utah, Journal of Sedimentary Research 64 (2) (1994), pp. 146-158.

Miller and West, 1993 K. B. Miller and R. R. West, Reevaluation of Wolfcampian cyclothems in northeastern Kansas: significance of subaerial exposure and flooding surfaces, Kansas Geological Survey Bulletin 235 (1993), pp. 1-26.

Montañez et al., $2007 \checkmark$ I. P. Montañez, N. J. Tabor, D. Niemeier, W. A. DiMichele, T. D. Frank, C. R. Fielding, J. L. Isbell, L. P. Birgenheier and M. C. Rygel, $\mathrm{CO}_{2}$-forced climate and vegetation instability during late Paleozoic deglaciation, Science 315 (2007), pp. 87-91.

Moore, 1934 R. C. Moore, Relations of cyclic depositional units in to the classification of the Pennsylvanian and Permian of the northern midcontinent region, Tulsa Geol. Soc. Dig. 1 (1934), pp. 18-20.

Moore, 1936 R. C. Moore, Stratigraphic classification of the Pennsylvanian rocks of Kansas, Kansas Geol. Surv. Bull. 22 (1936), pp. 1-256.

Moore and Moss, $1934 \longrightarrow$ R. C. Moore and R. G. Moss, Pennsylvanian-Permian boundary in the northern midcontinent area, Geologic Society of America Proceedings (Abst) 1933 (1934) p. 100.

Moore and Mudge, 1956 R. C. Moore and M. R. Mudge, Reclassification of some Lower Permian and Upper Pennsylvanian strata in the northern Midcontinent, Am. Assoc. Petrol. Geol. Bull. 40 (1956), pp. 2271-2278.

Mudge, 1956 M. R. Mudge, Sandstones and channels of the upper Pennsylvanian and lower Permian of Kansas, Am. Assoc. Petrol. Geol. Bull. 40 (1956), pp. $655-678$

Mudge and Yochelson, 1962 M. R. Mudge and E. L. Yochelson, Stratigraphy and paleontology of the uppermost Pennsylvanian and lowermost Permian rocks in Kansas, U. S. Geol. Surv. Prof. Pap. 323 (1962), pp. 1-213.

Nichols and Biggs, $1985 \triangleright$ M. N. Nichols and R. B. Biggs, Estuaries. In: R. A. Davis Jr., Editor, Coastal Sedimentary Environments, Springer Verlag, New York (1985), pp. 77-186.

Nio and Yang, $1991 \rightarrow$ S. D. Nio and C. S. Yang, Diagnostic attributes of clastic tidal deposits: a review. In: D. G. Smith, G. E. Reinson, B. A. Zaitlin and R. A. Rahmani, Editors, Clastic tidal sedimentology, Can Soc. Petrol. Geol. Mem. vol. 16 (1991), pp. 3-28.

Olszewski and Patzkowsky, 2003 T. D. Olszewski and M. E. Patzkowsky, From cyclothems to sequences: the record of eustacy and climate on an Icehouse epeiric platform (Pennsylvanian-Permian, North American Midcontinent), J. Sediment. Res. 73 (2003), pp. 15-30. otany and facies characteristics of a Pennsylvanian delta in southeastern Nebraska. Ph. D. thesis. University of Texas - Austin, Austin, Texas.

Pemberton and Wightman, 1992 S. G. Pemberton and D. M. Wightman, Ichnological characteristics of brackish water deposits. In: S. G. Pemberton, Editor, Application of Ichnology to Petroleum Exploration, SEPM Core Workshop vol. 17, SEPM, Tulsa (1992), pp. 141-168.

Plink-Bjorklund, $2005 \longrightarrow$ P. Plink-Bjorklund, Stacked fluvial and tide-dominated estuarine deposits in high-frequency (fourth-order) sequences of the Eocene Central Basin, Spitsbergen, Sedimentology 52 (2005), pp. 391-428.

Posamentier and Allen, 1999 H. W. Posamentier and G. P. Allen, Siliciclastic sequence stratigraphy - concepts and applications, SEPM concepts in Sedimentology and Paleontology vol. 7, SEPM, Tulsa (1999), pp. 1-204.

Reineck and Singh, 1986 H. E. Reineck and I. B. Singh, Depositional Sedimentary Environments, Springer-Verlag, New York, N. Y. (1986).

Ross and Ross, $1985 \rightarrow$ C. A. Ross and J. P. R. Ross, Late Paleozoic depositional sequences are synchronous worldwide, Geology 13 (1985), pp. 194-197.

Rygel et al., 2008 M. C. Rygel, C. R. Fielding, T. D. Frank and L. P. Birgenheier, The magnitude of late Paleozoic glacioeustatic fluctuations: a synthesis, J. Sediment. Res. 78 (2008), pp. 500-511.

Sawin et al., 2006 R. S. Sawin, R. R. West, E. K. Franseen, W. L. Watney and J R. McCauley, Carboniferous-Permian Boundary in Kansas, Midcontinent, U. S. A. Current Research in Earth Sciences. Kansas Geological Survey Bulletin 252, part 2; http://www.kgs.ku.edu/Current/2006/sawin/index.html

Shanley and McCabe, 1994 K. W. Shanley and P. J. McCabe, Perspectives on the sequence stratigraphy of continental strata, Am. Assoc. Petrol. Geol. Bull. 78 (1994), pp. 544-568.

Shanley et al., $1992 \rightarrow$ K. W. Shanley, P. J. McCabe and R. D. Hettinger, Tidal influence in Cretaceous fluvial strata from Utah, USA: a key to sequence stratigraphic interpretation, Sedimentology 39 (1992), pp. 905-930.

Soreghan and Giles, 1999 G. S. Soreghan and K. A. Giles, Facies character and stratal responses to accommodation in Pennsylvanian bioherms, western Orogrande Basin, New Mexico, J. Sediment. Res. 69 (1999), pp. 893-908.

Tessier, 1993 B. Tessier, Upper intertidal rhythmites in the Mont-SaintMichel Bay (NW France): perspectives for paleoreconstruction, Mar. Geol. 110 (1993), pp. 355-367.

Tessier et al., $1995 \rightarrow$ B. Tessier, A. W. Archer, W. P. Lanier, and H. R. Feldman, Comparison of ancient tidal rhythmites (Carboniferous of Kansas and Indiana, USA) with modern analogues (the Bay of Mont-saint-Michel, France). In: B. W. Fleming and A. Brotholoma, Editors, Tidal signatures in modern and ancient sediments, Spec. Pub. Int. Assoc. Sedimentologists vol. 24 (1995), pp. 259-271.

Van den Berg et al., 2007 J. H. Van den Berg, J. R. Boersma, and A. Van Gelder, Diagnostic sedimentary structures of the fluvial-tidal transition zone-Evidence from deposits of the Rhine and Meuse, Neth. J. Geosci. 86 (2007), pp. 287-306.

Van Wagoner et al., $1988 \rightarrow$ J. C. Van Wagoner, H. W. Posamentier, R. M. Mitchum, P. R. Vail, J. F. Sarg, T. S. Loutit, and J. Hardenbol, An overview of sequence stratigraphy and key definitions. In: C. Wilgus, B. S. Hasting, C. G. St. C. Kendall, H. W. Posamentier, C. A. Ross and J. C. Van Wagoner, Editors, Sea level changes - An Integrated approach, SEPM Special Publication vol. $\mathbf{4 2}$ SEPM, Tulsa (1988), pp. 39-45

Veevers and Powell, 1987 J. J. Veevers and C. McA. Powell, Late Paleozoic glacial episodes in Gondwanaland reflected in transgressive-regressive depositional sequences in Euramerica, Geol. Soc. Am. Bull. 98 (1987), pp. 475-487.

Wardlaw et al., $2004>$ B. R. Wardlaw, D. R. Boardman, and M. K. Nestell, Carboniferous-Permian Stratigraphy of the Midcontinent, Permophiles 44 (2004) pp. 25-28.

Zaitlin et al., 1994 B. A. Zaitlin, R. W. Dalrymple, and R. Boyd, The stratigraphic organization of incised-valley systems associated with relative sealevel change. In: R. W. Dalrymple, R. Boyd and B. A. Zaitlin, Editors, IncisedValley Systems: Origin and Sedimentary Sequences, SEPM Spec. Publ. vol. 51, SEPM, Tulsa (1994), pp. 45-60. 